\title{
Revisiting Controls on Shale Oil Accumulation in Saline Lacustrine Basins: The Permian Lucaogou Formation Mixed Rocks, Junggar Basin
}

\author{
Chenjia Zhang, ${ }^{1}$ Jian Cao $\mathbb{D}^{1}{ }^{1}$ Erting Li, ${ }^{2}$ Yuce Wang, ${ }^{1}$ Wenyao Xiao, ${ }^{1}$ and Yang Qin ${ }^{3}$ \\ ${ }^{1}$ State Key Laboratory for Mineral Deposits Research, School of Earth Sciences and Engineering, Nanjing University, \\ Nanjing 210023, China \\ ${ }^{2}$ PetroChina Xinjiang Oilfield Company, Karamay, Xinjiang 834000, China \\ ${ }^{3}$ PetroChina Research Institute of Petroleum Exploration \& Development-Northwest, Lanzhou 730020, China
}

Correspondence should be addressed to Jian Cao; jcao@nju.edu.cn

Received 10 September 2021; Accepted 1 October 2021; Published 31 October 2021

Academic Editor: Chao Liang

Copyright ( 92021 Chenjia Zhang et al. This is an open access article distributed under the Creative Commons Attribution License, which permits unrestricted use, distribution, and reproduction in any medium, provided the original work is properly cited.

Fine-grained mixed rocks in saline lacustrine basins are important targets for shale oil exploration. However, the controls on shale oil accumulation are complex due to the multi-source mixed deposition. This is a challenging issue in the study of shale oil. Here, we present a case study in the Middle Permian Lucaogou Formation in the Jimusar Sag, Junggar Basin, northwestern China. Results show that the Lucaogou Formation consists mainly of carbonate rocks, dolomitic or calcareous mudstones, tuffaceous or silty mudstones, and siltstones. The dolomitic/calcareous mudstones $\left(\mathrm{TOC}_{\text {average }}=6.44 \mathrm{wt} . \%\right)$ and tuffaceous/silty mudstones $\left(\mathrm{TOC}_{\text {average }}=4.83 \mathrm{wt} . \%\right)$ have the best hydrocarbon generation potential and contain type $\mathrm{I}_{-} \mathrm{II}_{1}$ kerogens that are in the peak oil generation stage. However, the shale oil potential is highest for the carbonate rocks and siltstones with average oil

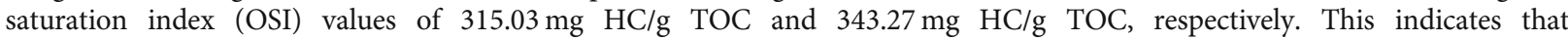
hydrocarbon generation potential is not the main factor controlling shale oil potential. Micro-nanoscale pores are the main control. Abundant dissolution pores provide excellent reservoir space for near-source migration and accumulation of shale oil. Different mixing processes between lithofacies control the accumulation of shale oil, and shale oil productivity is the best when multi-facies deposition in transitional zones formed the mixed rocks (facies mixing). In addition, local accumulations of calcareous organisms and adjacent carbonate components on terrigenous sediments (in situ mixing) are also conducive to shale oil enrichment. This is an unusual and special feature of saline lacustrine shale oils, which is different from freshwater lacustrine and marine shale oils. Comprehensive assessment of source rock and reservoir is needed to robustly establish a widely applicable method to determine the shale oil potential in such basins.

\section{Introduction}

Shale oil has increasing significance in petroleum exploration and exploitation worldwide [1-4], and such resource in China is mainly hosted in (saline) lacustrine sequence [5-8]. The exploration and exploitation of saline lacustrine shale oil is challenging due to multiple lithologies, dispersed sweet spots, and strong heterogeneity caused by the multi-source mixed sedimentary process. This is sharply different from the shale oil accumulation in marine shale reservoir systems, which are characterized by relatively simple lithologies and concentrated sweet spots [9-12].

Previous studies have obtained conflicting results regarding shale oil potential and its controls in saline lacustrine basins. For example, given that shale oil is retained in source rocks, it is proposed that the abundance, type, and maturity of organic matter control the shale oil potential [13-16]. However, other studies have shown that shale oil potential is closely related to the oil content, which is controlled by the hydrocarbon expulsion efficiency $[14,15,17,18]$. In 
addition, the exploitation and reserves of shale oil are also affected by the presence of micro-nanoscale pores and microfractures $[19,20]$, and thus, the reservoir properties are also important controls on the oil resource potential [21, 22]. Moreover, the ability to fracture shale oil reservoirs, as well as physical properties and occurrence and mobility of crude oil, is also important in controlling the shale oil potential [3, 13, 23-29]. In summary, controls on shale oil accumulation in saline lacustrine basins are not clear sufficiently and need further studies.

The Middle Permian Lucaogou Formation in the Jimusar Sag, Junggar Basin, China, is a representative example of shale oil in saline lacustrine basins and is the site of the first national shale-oil development base in China [30, 31]. As such, this reservoir is ideal for a study of what factors control shale oil accumulation in saline lacustrine basins. Previous studies of this formation have been carried out on its lithofacies, sedimentary environments, hydrocarbon generation potential, reservoir characteristics, and rock mechanics. In general, the Lucaogou Formation is considered to be a typically saline lacustrine shale reservoir, with an integrated source and reservoir that has excellent oil-bearing properties and is almost free of any structural controls [32-36]. However, due to its variable sedimentary environments and complex sedimentary-diagenetic history, the controls on shale oil accumulation remain unclear [13, 31, 36-39].

Therefore, to improve the understanding of controls on shale oil accumulation in saline lacustrine sequences based on the case study of the Lucaogou Formation, here, we conduct a comprehensive study of the sedimentary facies, petrology, organic geochemistry, and reservoir physical properties. More complex controls than previously thought were found, which can be referred to guide further exploration and have general significance for other saline basins.

\section{Geological Setting}

The Jimusar Sag is located in the southwestern region of the Eastern Uplift in the Junggar Basin (Figures 1(a) and 1(b)) and covers an area of about $1500 \mathrm{~km}^{2}$ [30]. The sag has experienced multiple cycles of tectonism and sedimentation [31, 40-43]. It was formed in the Late Carboniferous to Early Permian when the Jimusar fault was initially formed. The Bogeda Trough on the southern margin of the basin began to close orogenically in the late Early Permian, which caused the Jimusar Sag to begin to subside intensely, forming into a foreland dustpan-shaped sag. Until the middle to late Middle Permian, the study area further underwent strong subsidence with independent deposition, forming the main source rock of shale oil in this area (i.e., Lucaogou Formation). At the end of the Late Triassic, influenced by the Indosinian orogeny, the sag began to uplift greatly, and part of the Permian and Triassic strata in the eastern slope were denuded. During the Cretaceous period, due to the influence of Yanshanian orogeny, the tectonic activities of the Jimusar Sag were slightly active. The southeast part of the sag gradually uplifted and contracted to the northwest, and the independent pattern disappeared. Until the Paleogene and Quaternary periods, under the influence of Himalayan orogeny, the Bogeda Mountains to the south of the sag were uplifted rapidly and thrust towards the center of the basin. The strata in the Jimusar Sag gradually thinned from west to east, and the present tectonic pattern is formed. This resulted in fault-related subsidence in the western part of the sag, uplift in the eastern part of the sag, and coeval faulting and uplift in the northern and southern areas of the sag [31, $41,42]$. In general, the topography of the sag is smoothly undulating, strata are continuous, and secondary faults are rare. The sag has a relatively simple monoclinic dustpan-like structure (Figure 1(c)). The western part of the sag is a low-lying area, and the eastern part is a slope zone. The low-lying area to the slope zone includes the main shale oil and gas production areas.

The studied Lucaogou Formation was deposited in a deep saline lake with shallow to semi-deep lake and delta facies in marginal places. The burial depth is about 2500 $4500 \mathrm{~m}$ [30, 31, 34, 36]. The Lucaogou Formation consists of variable lithologies, with a large amount of terrigenous sediments and carbonates and a small amount of pyroclastic rocks, which form a mixed sedimentary system with a thickness of about $\sim 90-350 \mathrm{~m}[44,45]$ (Figure 1). The two sites with the best oil production are termed the "upper sweet spot" $\left(\mathrm{P}_{2} \mathrm{l}_{2}{ }^{2}\right)$ and "lower sweet spot" $\left(\mathrm{P}_{2} \mathrm{l}_{1}{ }^{2}\right)$, and there is a thick mudstone section between the two sweet spots [30, $34,46]$. The crude oil produced in the upper and lower sweet spots is mainly heavy oil, with a density of $0.88-0.92 \mathrm{~g} / \mathrm{cm}^{3}$.

\section{Samples and Methods}

A total of 313 representative samples from different units and lithofacies in seven wells, including the J10025, J301, J303, J305, J43, J251, and J174 wells, were analyzed. Well J10025 was the focus of this study as the Lucaogou Formation was systematically cored in this well (Figures 1(b) and 2). The core samples and thin sections of all 313 samples were first observed. Based on these observations, total organic carbon (TOC) content, Rock-Eval pyrolysis, and vitrinite reflectance analyses were undertaken on 154 representative samples, and $\mathrm{X}$-ray diffraction (XRD) analysis was conducted on 66 representative samples of different lithofacies. In addition, 45 samples were subjected to nuclear magnetic resonance (NMR) analysis, and 12 samples were examined by field emission scanning electron microscopy (FE-SEM).

3.1. Petrology and Mineralogy. Fresh rock samples were cut perpendicular to the bedding and made into polished thin sections following the procedures of Taylor et al. [47] and Amijaya and Littke [48]. A Nikon ECLIPSE LV100N POL microscope was used for thin section observations at the State Key Laboratory for Mineral Deposits Research, School of Earth Sciences and Engineering, Nanjing University, Nanjing, China. The transmitted and reflected light source was a $100 \mathrm{~W}$ halogen lamp, and a $100 \mathrm{~W}$ mercury lamp was used for the fluorescence observations.

XRD analysis was also conducted at the State Key Laboratory for Mineral Deposits Research, School of Earth Sciences and Engineering, Nanjing University. Prior to analysis, the samples were dried at $40^{\circ} \mathrm{C}$ for $24 \mathrm{~h}$ and then powdered to 200 mesh in an agate mortar. A DMAX Rapid II X-ray 


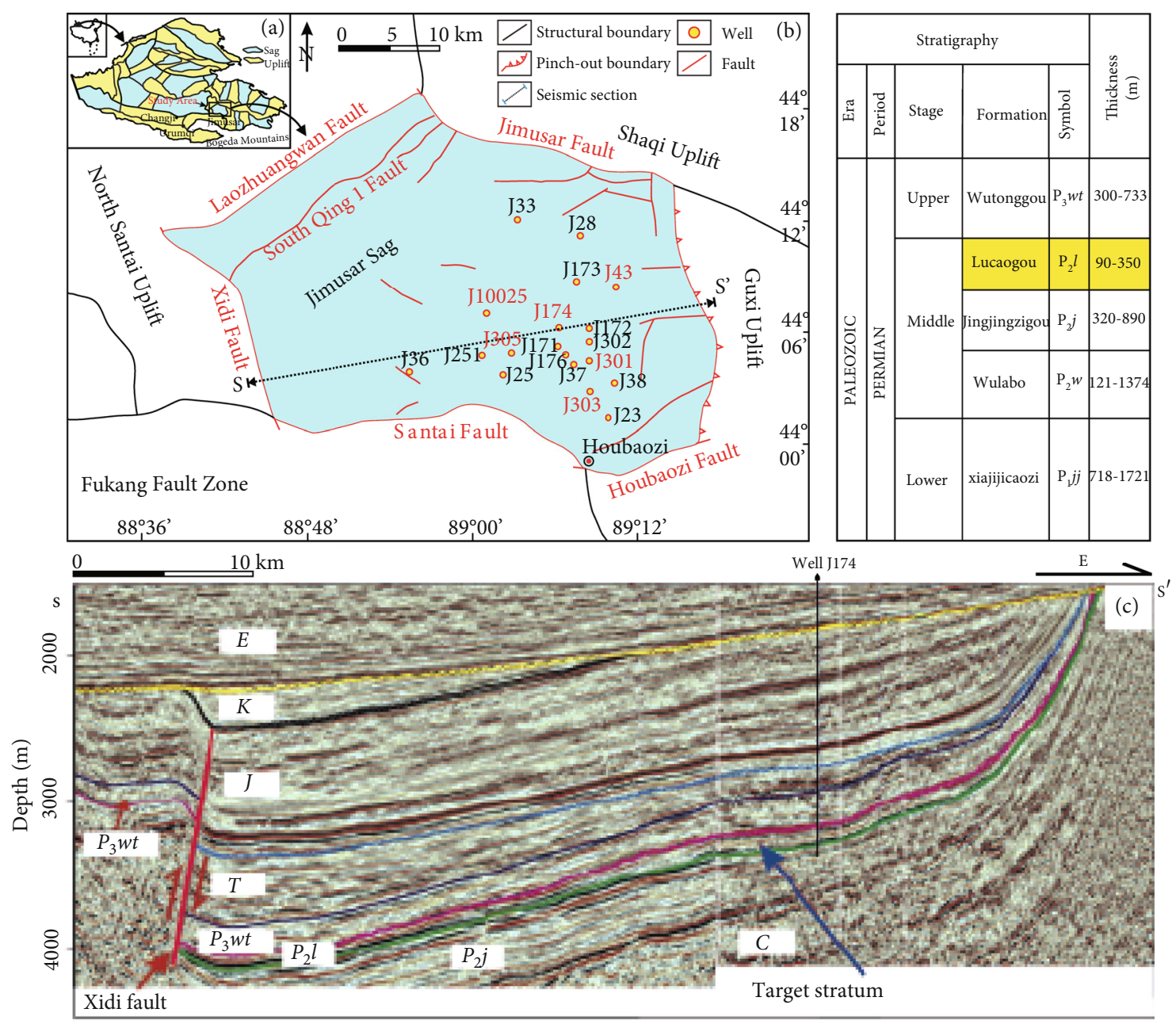

Figure 1: Structural and stratigraphic framework of the Jimusar Sag (modified after PetroChina Xinjiang Oilfield Company's data [46, 75]). (a) Location of the Jimusar Sag in the Junggar Basin. (b) Structural framework and distribution of major wells in the Jimusar Sag. (c) Seismic section showing the stratigraphy of the Jimusar Sag.

diffractometer was used for the analysis with $\mathrm{Mo-K} \alpha$ radiation. The instrument was operated at $50 \mathrm{kV}$ and $90 \mathrm{~mA}$. The measurement range of the mineral diffraction angle $(2 \theta)$ was $-45^{\circ}$ to $165^{\circ}$, and the recording range of the azimuth angle $(\beta)$ was $360^{\circ}$ when $2 \theta \leq 45^{\circ}$.

3.2. Organic Geochemistry. The organic geochemical analyses were undertaken at the MOE Key Laboratory of Surficial Geochemistry, School of Earth Sciences and Engineering, Nanjing University. The TOC contents were determined with an Elementar Vario MACRO CHNS elemental analyzer. The fresh samples were first powdered to 100 mesh and treated with $10 \% \mathrm{HCl}$ for $48 \mathrm{~h}$ to remove carbonates. The samples were then repeatedly rinsed in deionized water and centrifuged until the supernatant had a $\mathrm{pH} \sim 7$. Finally, the samples were dried at $60^{\circ} \mathrm{C}$ for $48 \mathrm{~h}$ and analyzed.

The pyrolysis parameters were determined with a RockEval IV instrument. Unaltered samples were first powdered to $<100$ mesh, placed in a He atmosphere, and heated at a constant temperature of $300^{\circ} \mathrm{C}$ for 3 minutes. The temperature was then increased to $600^{\circ} \mathrm{C}$ at a rate of $25^{\circ} \mathrm{C} / \mathrm{min}$ to obtain the free hydrocarbon $\left(S_{1}\right.$, mg HC/g rock), cracked hydrocar- bon $\left(S_{2}, \mathrm{mg} \mathrm{HC} / \mathrm{g}\right.$ rock), and $\mathrm{CO}_{2}$ contents $\left(S_{3}, \mathrm{mg} \mathrm{HC} / \mathrm{g}\right.$ rock). The temperature corresponding to the $S_{2}$ peak value is the pyrolysis peak temperature $\left(T_{\max }\right)$.

3.3. Reservoir Space. The residual liquid hydrocarbons in samples can affect measurements of the pore size distribution. Therefore, before analyzing the reservoir space, all samples were Soxhlet extracted using a mixture of dichloromethane and methanol (93:7 volume ratio) to remove oil.

Field emission scanning electron microscopy (FE-SEM) observations with an X-ray energy-dispersive spectrometer (EDS) were conducted at the State Key Laboratory for Mineral Deposits Research, School of Earth Sciences and Engineering, Nanjing University. The instrument used is an S-3400N II scanning electron microscope (Hitachi Ltd., Japan). Blocks of an appropriate size and flat surfaces were fixed on a short plate with brackets, and the samples were then coated with Pt-Pd using a Polaron E5000 sputter coater at $1.2 \mathrm{kV}$ for $2 \times$ $2 \mathrm{~min}$. The instrument was operated at an accelerating voltage of $15.0 \mathrm{kV}$ and beam current of $1.0-2.0 \times 10^{-9} \mathrm{~A}$.

NMR $T_{2}$ spectra were obtained with a Numai NMRC12$010 \mathrm{~V}$ nanopore analyzer at the MOE Key Laboratory of 

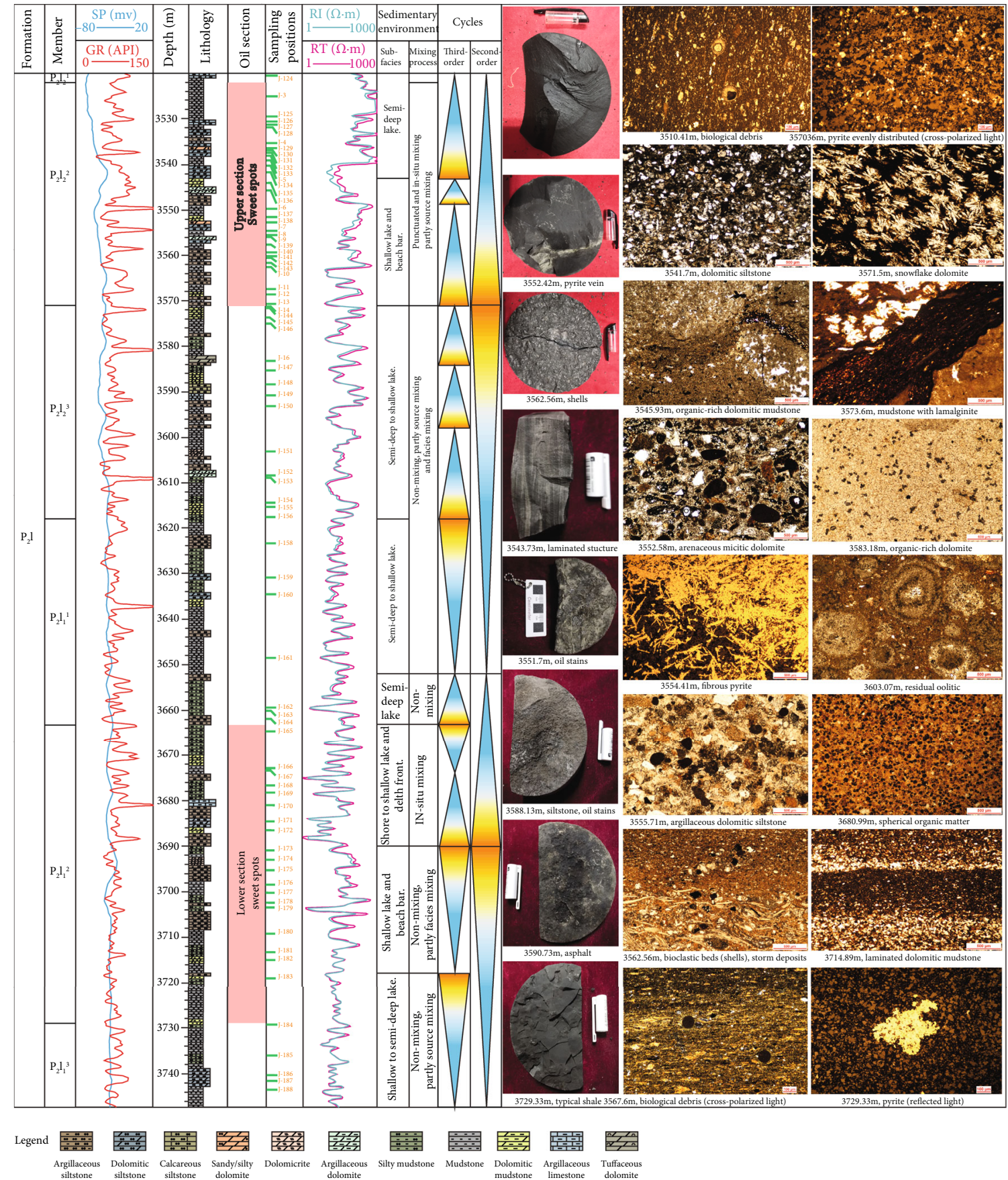

Figure 2: Composite columnar section of well J10025 in the Jimusar Sag. The location of the well is shown in Figure 1(b). The logging data and samples were collected by PetroChina Xinjiang Oilfield Company.

Surficial Geochemistry, School of Earth Sciences and Engineering, Nanjing University. The experimental parameters were as follows: waiting time $=5000 \mathrm{~ms}$; echo number $=$ 2048; echo interval $=0.1 \mathrm{~ms}$; and numbers of scans $=128$. Prior to the analyses, the samples were cut into cylindrical shapes with diameters of $1.5 \mathrm{~cm}$ and heights of $1 \mathrm{~cm}$. All the samples were analyzed twice, the first time on the original samples and the second time after the samples were saturated with deionized water for $12 \mathrm{~h}$ under vacuum. The first analysis (i.e., the background values) was subtracted from the second analysis, which yielded the actual pore size distribution curve of the samples.

\section{Results}

4.1. Sedimentary Features. The Lucaogou Formation in the Jimusar Sag consists of dolomites and mudstones, with variable components and structures. Well J10025 is in the deep depression area in the central part of the sag, and in this well, the Lucaogou Formation shows a complete lacustrine regressive- 


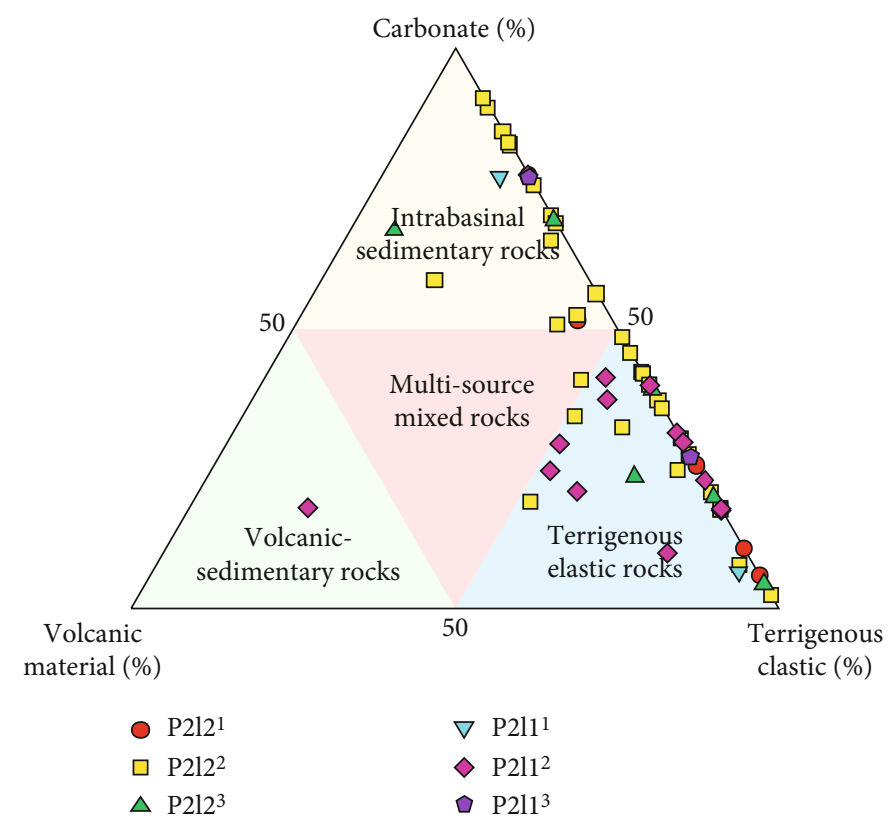

(a)

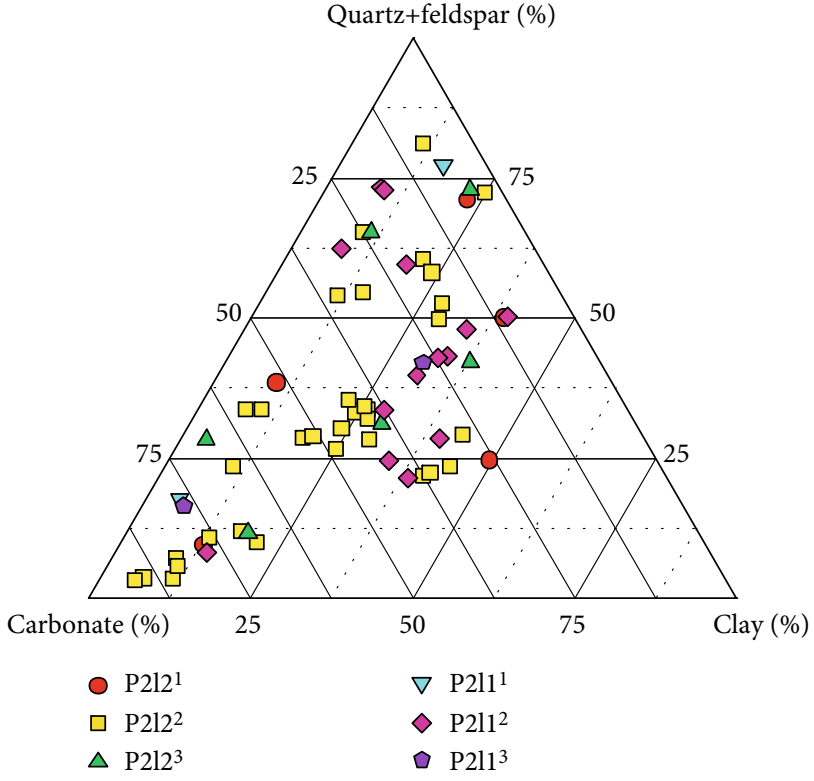

(b)

Figure 3: Classification system of rocks in the Lucaogou Formation, Jimusar Sag. (a) Ternary diagram of carbonate, volcanic, and terrigenous clastic material contents. (b) Ternary diagram of carbonate, clay, and felsic mineral contents.

transgressive sequence, and two complete sedimentary cycles develop from base to top (Figure 2). The lake level first decreased gradually, transforming $\mathrm{P}_{2} \mathrm{l}_{1}^{2}$ from lacustrine to deltaic facies, and then the lake level rose gradually, resulting in a thick mudstone section being deposited on $\mathrm{P}_{2} \mathrm{l}_{1}{ }^{1}$. During deposition of $\mathrm{P}_{2} \mathrm{l}_{2}{ }^{3}$, the lake level began to fall slowly, and the sedimentary microfacies at the margin of the basin changed into shallow lake beach bars and dolomitic flat facies. In general, the lake level fluctuated frequently, and numerous thin layers of terrigenous clastic rocks are interbedded with carbonate rocks. The main sedimentary facies include deltas, beach bars, carbonate shores, and dolomitic flats, which all represent shallow water environments. There was also deposition in mud flat and deep lake facies in deeper water settings.

Well J10025 is dominated by dolomitic mudstone intercalated with siltstone, and dolomitization is quite obvious. Terrigenous clastics and dolomitic rocks are also prevalent. The dolomite is mainly micrite, with occasional calcareous clastic and residual oolitic structures. Bioclastic and organic matter are widely distributed in the strata (Figure 2). The bioclastic limestone and dolomicrite contain less clastic and volcanic materials, whereas the limestone and dolomite contain mud, silt, and sand representing a mixture and a transition of fine-grained terrigenous clastics and carbonates that were deposited in shallow to semi-deep lake facies. Terrigenous clastic rocks were mainly deposited in sandy microfacies, such as beaches and bars, near terrigenous source areas. In the evaporatic zone around the basin distal from the terrigenous sources, a small amount of terrigenous clastic materials was delivered and deposited by lake waves, shore currents, and storms, forming thin layers of carbonates and silty sands.
The lower sweet spot consists mainly of dolomitic/argillaceous siltstone and silty mudstone and occasionally dolomitic/calcareous mudstone and dolomicrite. The sedimentary environments include shallow lakes, beach bars, and delta facies, and the dominant source was terrigenous. Calcite recrystallization and dolomitization are quite obvious. Mineral veins, pyrite, and silt content are high in the lower sweet spot (Figure 2). The terrigenous materials may have been transported into the middle of the lake basin by waves due to early delta or shoreline erosion, where they coexisted with the dolomites.

The upper sweet spot consists mainly of dolomitic/argillaceous siltstone, dolomitic mudstone, and some calcareous siltstone and mudstone. The sedimentary environments include shallow and semideep lake and beach bar facies. Bioclastic layers with abundant randomly oriented shells which are indicative of storm events were observed in cores and thin sections (Figure 2). Algae, organic matter, and fibrous pyrite occur in the upper sweet spot. Compared with the lower sweet spot, the dolomite and silt contents are higher and lower, respectively. In general, the supply of terrigenous material to the saline lacustrine basin is lessened with time, and the climate was hot and led to strong evaporation.

The middle section between the two sweet spots consists mainly of fine-grained mudstone, which may contain traces of biological activity, such as oolites (Figure 2). Mud-rich carbonate rocks were mostly formed in lower-energy sedimentary environments and are fine-grained and relatively dark in color. The granular carbonate rocks composed of particles such as oolites, intraclasts, and biological clastics are often formed in shallow water, as well as other higherenergy sedimentary environments. 


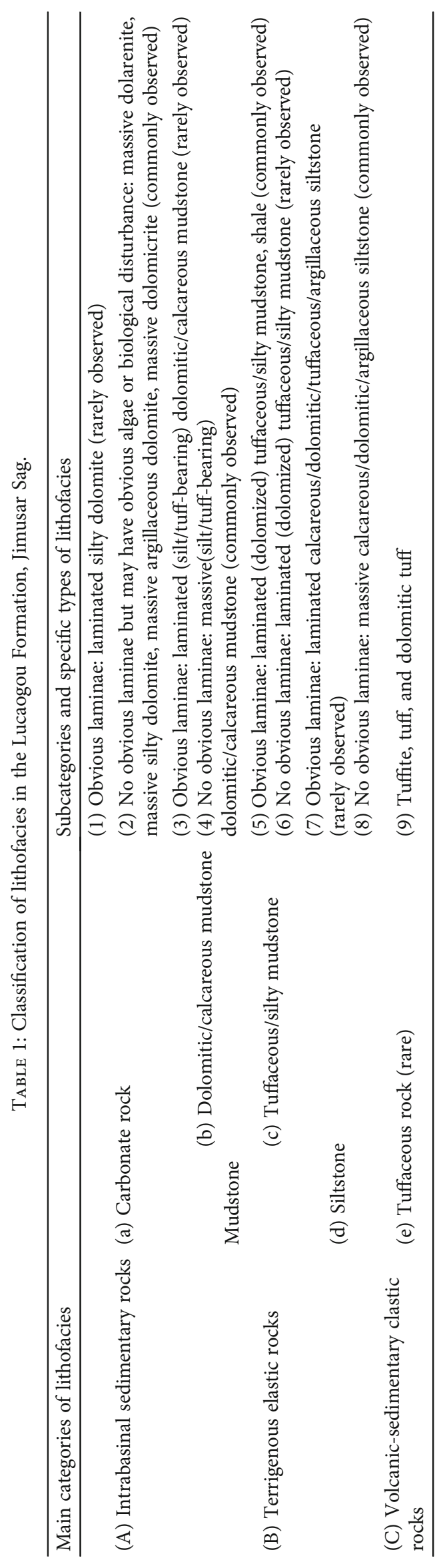




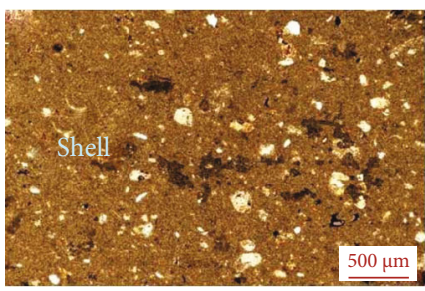

(a)

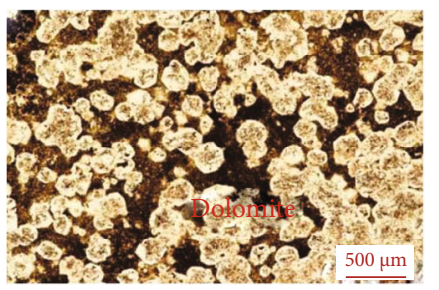

(c)

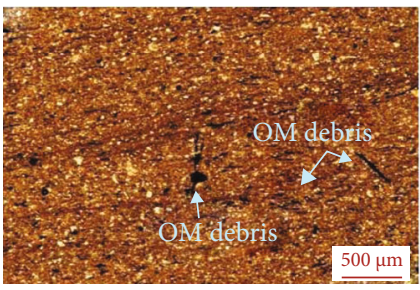

(e)

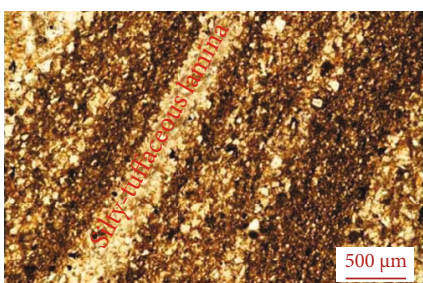

(g)

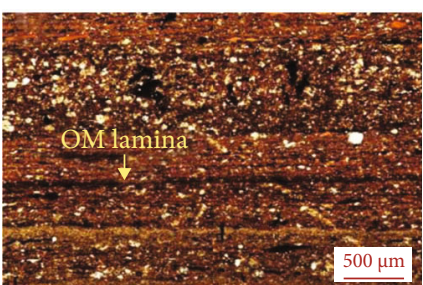

(i)

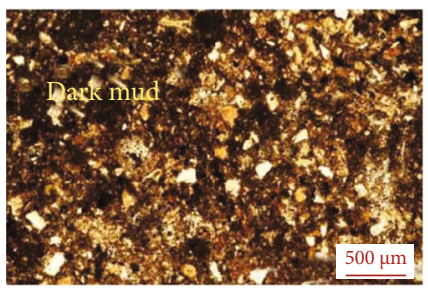

(k)

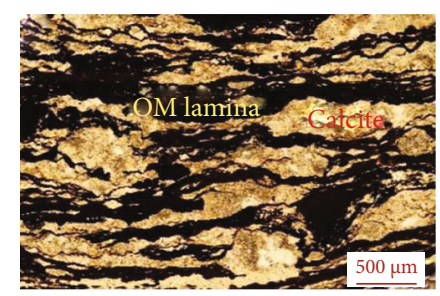

(b)

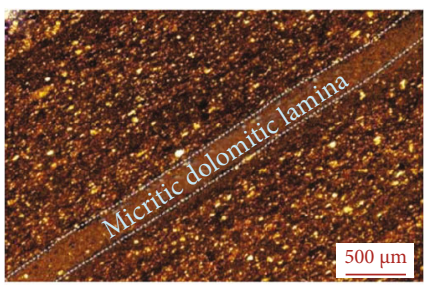

(d)

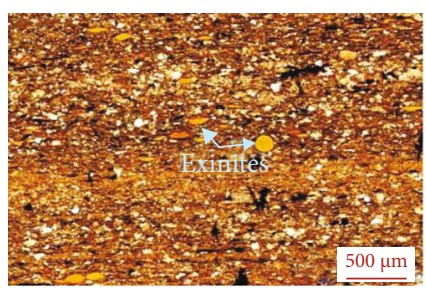

(f)

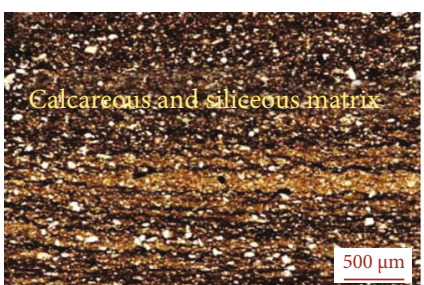

(h)

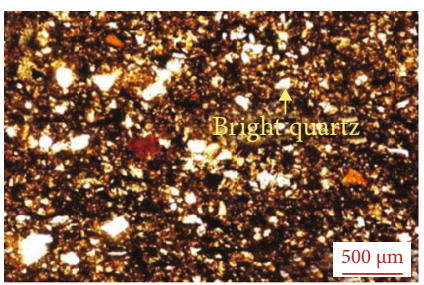

(j)

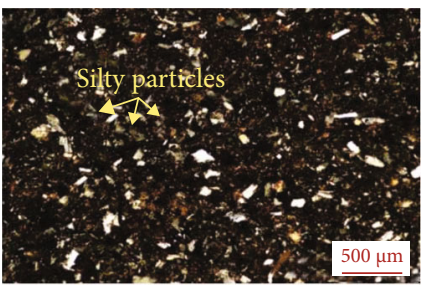

(1)

FIgURe 4: Continued. 


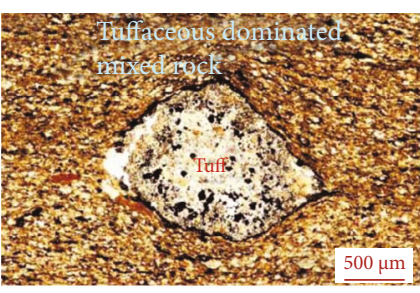

(m)

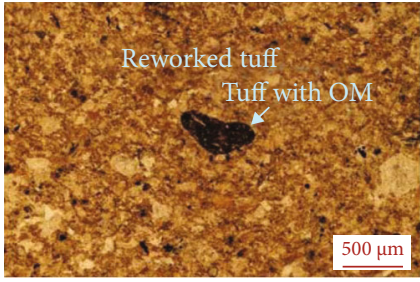

(n)

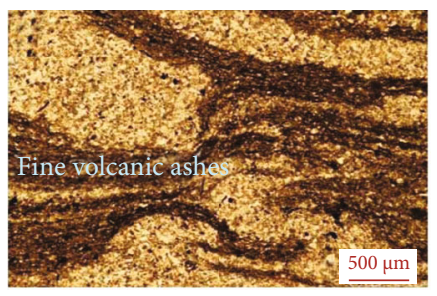

(o)

FIgURE 4: Photomicrographs of the main lithologies in the Lucaogou Formation, Jimusar Sag: (a) well J305, 3409.01 m, shell-rich dolomicrite with silts; (b) well J303, $2602.53 \mathrm{~m}$, micrite containing abundant organic matter laminae; (c) well J301, $2779.27 \mathrm{~m}$, argillaceous dolomite containing opaque (center) and clean (rim) dolomite, which is recrystallized into a granular texture; (d) well J303, $2595.5 \mathrm{~m}$, dolomitic mudstone containing micritic dolomitic laminae; (e) well J305, $3554.54 \mathrm{~m}$, dolomitic mudstone containing higher plant debris; (f) well J43, $2948.5 \mathrm{~m}$, dolomite mudstone containing silt and abundant vitrinite (microspores); (g) well J305, $3568.51 \mathrm{~m}$, tuffaceous mudstone with silt laminae; (h) well J251, $3786.61 \mathrm{~m}$, dolomitic silty mudstone; (i) well J43, $2948.5 \mathrm{~m}$, shale containing silt and organic matter laminations; (j) well J305, $3546.15 \mathrm{~m}$, argillaceous siltstone; (k) well J303, $2594.8 \mathrm{~m}$, argillaceous marly siltstone; (l) well J43, $2950.5 \mathrm{~m}$, argillaceous siltstone (cross-polarized light); (m) well J303, 2576 m, dolomitic tuff; (n) well J305, 3546.15 m, tuff; (o) well J305, 3560.54 m, intermittent laminated tuffite.

In general, the lake level fluctuated very frequently during the deposition of the Lucaogou Formation. In the area near the terrigenous source, clastic sediments are more abundant as compared with carbonates. On the contrary, in the area near the center of the deep lake, carbonates are dominant. In the sweet spot sections, argillaceous dolomite and dolomitic mudstone formed mainly in low-energy environments. In higher energy settings, silt and volcanic materials from the basin margins were carried by waves and storms and deposited, which formed a mixing deposit of carbonate and terrigenous material (including volcanic debris).

4.2. Classification of the Multisource Mixed Rocks. For typical samples, we estimated the relative percentages of carbonate, terrigenous clastic, and volcanic material, based on XRD data and microscopic observations (Figure 3(a)). If the contents of all three components are $<50 \%$, the name of the sample is determined by the components with the highest and second highest relative contents. Thus, the lithofacies can be divided into intrabasinal sedimentary rocks (i.e., carbonate rocks), terrigenous clastic rocks, volcanic-sedimentary clastic rocks, and multisource mixed rocks (Figure 3(a), Table 1). We then considered the relative contents of different minerals in the specific rock components, such as the relative contents of felsic minerals and clay minerals in the terrigenous clastic and calcite and dolomite in the carbonates. The three-level nomenclature $(10 \%, 25 \%$, and $50 \%)$ was followed, and the rock structures were also taken into account when further classifying the rock types (e.g., laminae and bioclasts) (Figures 3(a) and 4, Table 1).
Our results show that there are few single-component rocks in the Lucaogou Formation, and multisource finegrained mixed rocks are common, which can be divided into three main categories, five subcategories, and nine specific types (Table 1). The first category is intrabasinal sedimentary rocks, which are dominated by carbonate minerals and are mainly carbonate rocks with terrigenous clastic material (Table 1, Figures 4(a)-4(c)). Most of these rocks have massive structures. The Lucaogou Formation comprises mainly dolomicrites containing a bit of silts and sands. These lithofacies are least affected by terrestrial and volcanic material and were mainly deposited inside the basin.

The second category is terrigenous clastic rocks, which consist mainly of silty material and clay minerals. This category includes mudstone (particle size $<4 \mu \mathrm{m}$ ) and siltstone (particle size $=4.0-62.5 \mu \mathrm{m})$ (Table 1). The mudstones are divided into two subcategories (Table 1), including mudstone with a high carbonate content (Figures 4(d)-4(f)) and mudstone dominated by volcanic material or silt (Figures $4(\mathrm{~g})$ and $4(\mathrm{~h}))$. The mudstones were deposited in lower energy hydrodynamic conditions and contain horizontal laminae. However, the average clay mineral content is not high in Lucaogou mudstones (average $=29.6 \%$ ). This lithological category is mostly mixed with carbonate or terrigenous clastics and tuffaceous materials, indicating that the terrigenous materials exposed along the shore of the saline lacustrine basin prograded into the basin. Carbonate components precipitated through capillary dolomitization in the evaporatic environment. The siltstones are dominated by terrigenous materials (Figures 4(j)-4(l)), mainly including quartz, K-feldspar, 
plagioclase, and analcime, and also mixed with carbonates (dolomite, calcite, ankerite, and siderite) and volcanic ash. The siltstones are commonly interbedded with mudstones.

The third category is volcanic-sedimentary rocks, which transition from volcanic to sedimentary rocks. In the Lucaogou Formation, these rocks are mainly tuffite, tuff, and dolomitic tuff (Table 1, Figures 4(m)-4(o)). Sporadic pyroclastic material was observed in different well sections irregularly, indicating that air-fall tuffs were mainly deposited over the basin by winds. The tuff and dolomitic tuff are mostly massive or weakly layered (Figures $4(\mathrm{~m})$ and $4(\mathrm{n})$ ), and some tuffaceous materials may have been water reworked during deposition, thus forming weak horizontal bedding. The tuffite comprises mostly fine-grained volcanic ash that is laminated (Figure 4(o)). The laminae are mostly discontinuous and have lenticular, dish, funnel, and other irregular shapes, which may be related to uneven deposition of the tuff material, bioturbation, or slight modification by water flow.

In summary, the Lucaogou Formation comprises finegrained mixed rocks consisting of terrigenous clastics, carbonates, and volcanic materials. Most of the rocks contain a mixture of two or three components. In particular, mudstones are widely developed. In addition, dolomite, feldspar, and quartz are abundant. In comparison, volcanic materials are a minor component. Therefore, we term the four main types of lithology: carbonate rock, dolomitic/calcareous mudstone, tuffaceous/silty mudstone, and siltstone.

\subsection{Organic Geochemistry}

4.3.1. Organic Matter Contents. The organic matter contents of the four main lithologies in the Lucaogou Formation are shown in Figure 5(a). Based on the evaluation criteria of Peters and Cassa [49], most of the samples with TOC $>2.0$ wt. $\%$ and $\mathrm{PG}\left(S_{1}+S_{2}\right)>20 \mathrm{mg} \mathrm{HC} / \mathrm{g}$ rock are very good source rocks. In general, the TOC contents and PG values exhibit a good correlation. The TOC contents of the siltstones and carbonate rocks are lower than those of the mudstones (Figure 5(a)); nonetheless, many of the siltstones and carbonate rocks with TOC $>2$ wt. \% have certain hydrocarbon generation potential. The tuffaceous/silty mudstones have the highest TOC contents (1.00-27.08wt.\%, average $=6.44$ wt.\%) and $\mathrm{PG}$ values of $7.06-137.20 \mathrm{mg} \mathrm{HC/g}$ rock (average $=41.68 \mathrm{mg} \mathrm{HC} / \mathrm{g}$ rock). The dolomite/lime mudstones have the second highest TOC contents of $1.06 \%-$ 25.34 wt. $\%$ (average $=4.83$ wt.\%) and PG values of 3.58$101.75 \mathrm{mg} \mathrm{HC} / \mathrm{g}$ rock (average $=29.19 \mathrm{mg} \mathrm{HC} / \mathrm{g}$ rock). In summary, the mudstones have the best organic richness.

4.3.2. Organic Matter Types. We used plots of $T_{\max }$ versus the hydrogen index ( $\left.\mathrm{HI}=S_{2} \times 100 / \mathrm{TOC}\right)$, HI versus the oxygen index (OI $=S_{3} \times 100 /$ TOC), and Rock-Eval pyrolysis $S_{2}$ versus TOC to determine the organic matter types [49-51]. The results show that the organic matter in the Lucaogou Formation is predominantly types $\mathrm{I}_{1} \mathrm{II}_{1}$, and $\mathrm{II}_{2}$ and rarely type III (Figures 5(b)-5(d)). The mudstones contain type I kerogen in dominance, and some siltstones and dolomites contain types $\mathrm{II}_{1}$ and $\mathrm{II}_{2}$ kerogens. These suggest that the Lucaogou source rocks are generally oil-prone. However, there are some differences between the lithologies, as the organic matter type in the mudstones is relatively the most conducive to oil generation.

4.3.3. Thermal Maturity of Organic Matter. Most of the analyzed mudstones have $T_{\max }>435^{\circ} \mathrm{C}$ (Figure 5(e)), suggesting the samples are mature [49]. Due to the greater burial depth, some mudstones in the lower sweet spot have reached the main oil generation window $\left(T_{\max }=450-470^{\circ} \mathrm{C}\right)$ [52]. Some of the carbonate rocks and siltstones are immature to lowly mature. In summary, most of the organic matter in different lithofacies of the Lucaogou Formation are of low maturity to mature and are close to or have reached the oil generation window.

4.4. Reservoir Space. For characterizing the multiscale pore size distribution of the Lucaogou shale oil reservoir, a variety of methods were used. Observations of cores and thin sections were employed to describe the distributions of macroscopic pores. FE-SEM can reveal the characteristics of nanoscale pores, and the NMR $T_{2}$ spectra reflect the overall distribution of the nano-microscale pores.

\subsubsection{Reservoir Space Type}

(1) Thin Section Observations. The Lucaogou Formation contains micron-scale fractures and pores (Figure 6). There are various types of fracture and pore systems, and the fractures mainly include diagenetic or structural fractures, bedding cracks, and stylolites (Figures 6(a)-6(c)). The pores are mainly carbonate intercrystalline, dissolution, intragranular, and terrigenous clastic intergranular pores (Figures 6(d)-6(i)).

The irregular structural fractures are generally filled with organic matter (Figure 6(a)). They may also be filled with carbonates, such as calcite or dolomite, with widths ranging from a few to tens of microns, which are developed in carbonate rocks, as well as mudstones and siltstones. The laminated mudstones easily have bedding cracks (Figure 6(b)), especially at the contact zones between laminae of different compositions. In addition, pressure solution has caused stylolites to develop in the shale, which are mostly filled with organic matter (Figure 6(c)).

The size of pores under thin section observation varies from a few to a few hundred microns, with different formation mechanisms. The intercrystalline and intragranular pores in carbonate rocks are distributed in the matrix and veins and are often filled with asphaltenes. The pore size is several to tens of microns (Figures 6(d)-6(h)). The acidic fluid generated during the diagenesis and hydrocarbon generation process may have dissolved unstable minerals. The rock matrix has also formed pores related to hydrocarbon generation and expulsion. Such pores are widely distributed in the carbonate rocks, including in the matrix, intergranular, and within laminae. The pore size is generally large, and the pores may be filled with asphaltene or calcite or both (Figures $6(\mathrm{~d})-6(\mathrm{~g})$ and $6(\mathrm{i})$ ).

In summary, the thin section observations show that the carbonate rocks, mudstones, and siltstones contain fractures and dissolution pores. Dissolution pores are more widely 


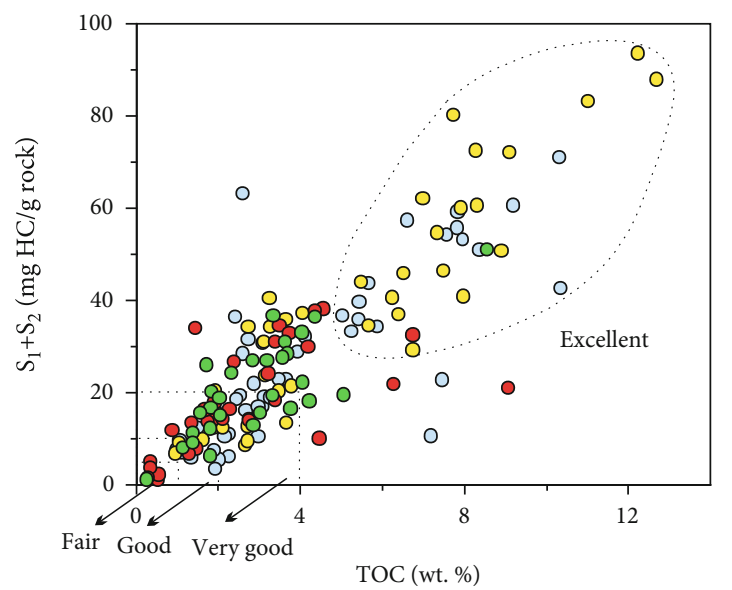

(a)

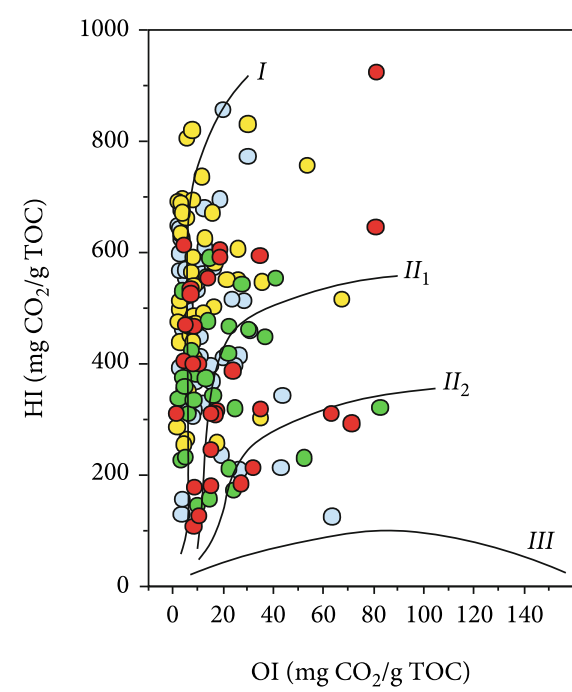

(c)

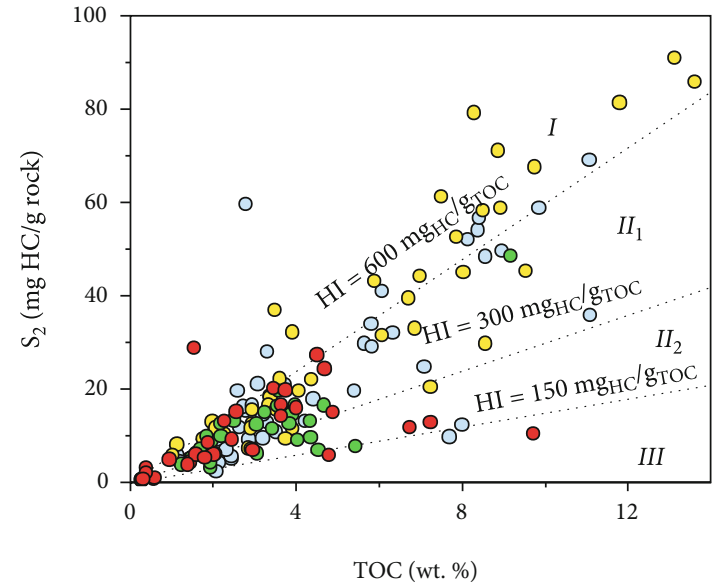

(b)

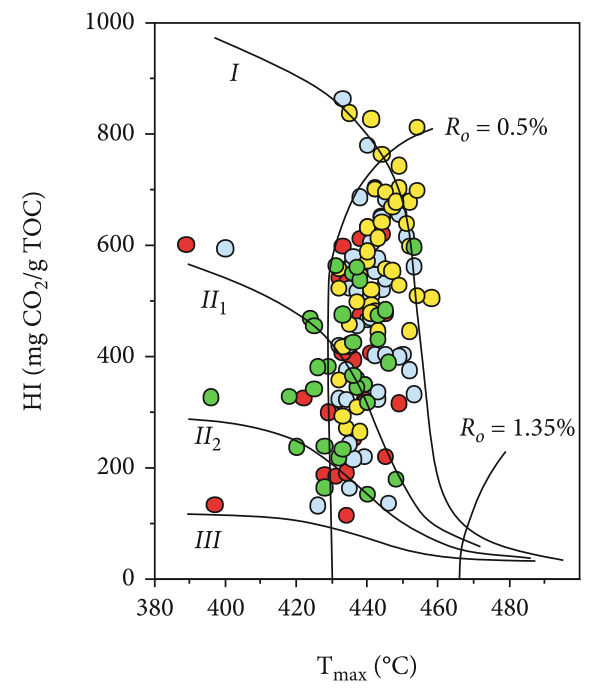

(d)

$\mathrm{T}_{\max }\left({ }^{\circ} \mathrm{C}\right)$

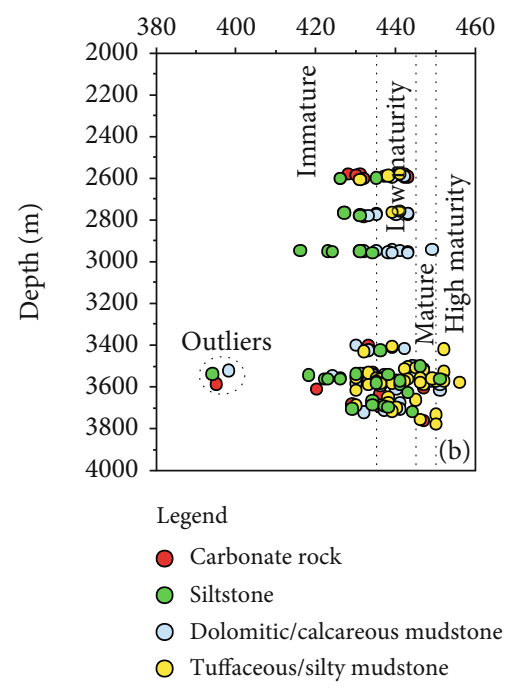

(e)

Figure 5: Organic matter contents, types, and maturity in the Lucaogou Formation, Jimusar Sag. (a) Organic matter contents of the different lithologies. (b) Rock-Eval pyrolysis $S_{2}$ values versus TOC contents. (c) HI values versus OI plot. (d) HI values versus $T_{\max }$ plot. (e) $T_{\max }$ versus depth plot. The evaluation criteria are from [49]. 


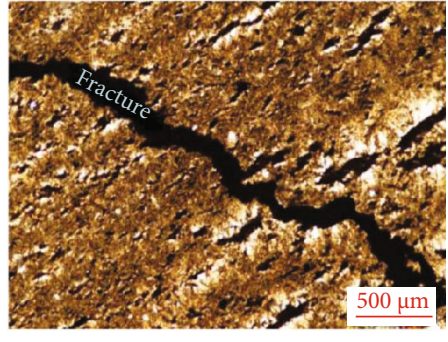

(a)

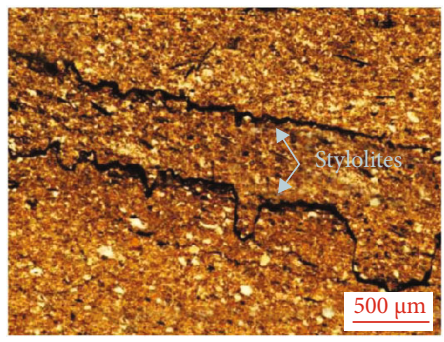

(c)

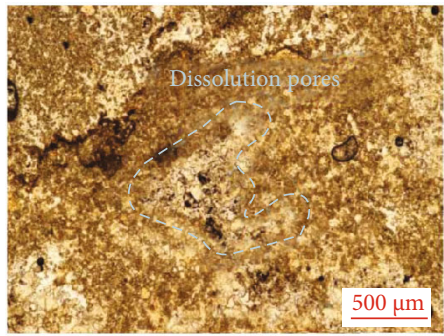

(e)

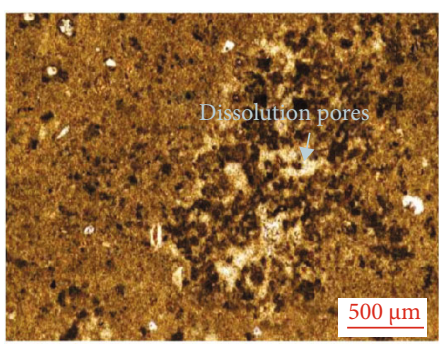

(g)

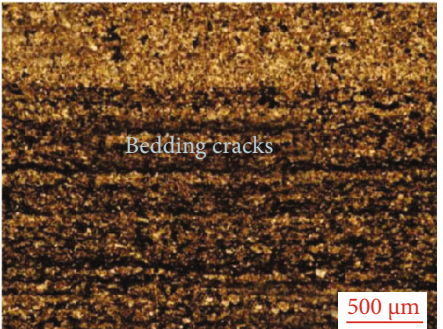

(b)

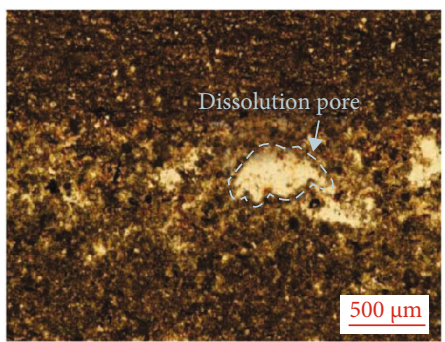

(d)

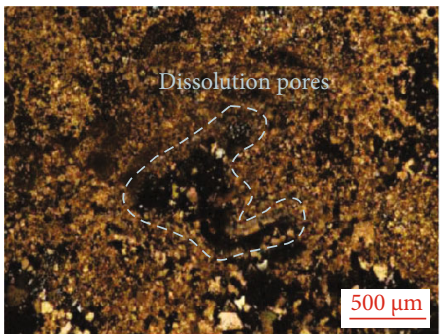

(f)

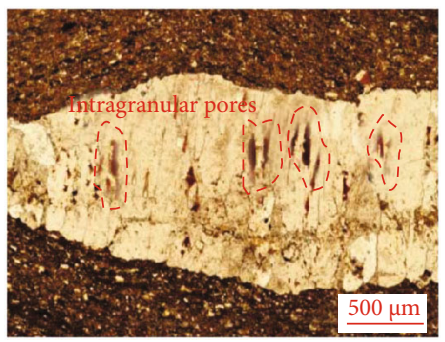

(h)

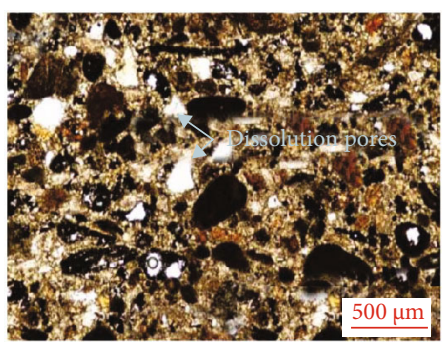

(i)

FIGURE 6: Photomicrographs showing the reservoir space types in the Lucaogou Formation, Jimusar Sag: (a) well J10025, 3516.15 m, dolomitic mudstone with fractures; (b) well J303, $2600.31 \mathrm{~m}$, dolomitic silty mudstone with bedding cracks filled with organic matter; (c) well J305, $3582.73 \mathrm{~m}$, stylolites filled with organic matter (plane-polarized light); (d) well J43, $2947.45 \mathrm{~m}$, calcareous siltstone with dissolution pores (plane-polarized light); (e) well J301, $2768.3 \mathrm{~m}$, argillaceous dolomite showing iron dolomitization and dissolution and intercrystalline pores (plane-polarized light); (f) the same field of view as (e) but in cross-polarized light; (g) well J301, 2771.8 m, dolomicrite with abundant dissolution pores (plane-polarized light); (h) well J43, $2953 \mathrm{~m}$, abundant intragranular pores in the veins of carbonate minerals, which are filled with organic matter (plane-polarized light); (i) well J10025, 3552.58 m, dolarenite with abundant dissolution and intergranular pores (plane-polarized light). 


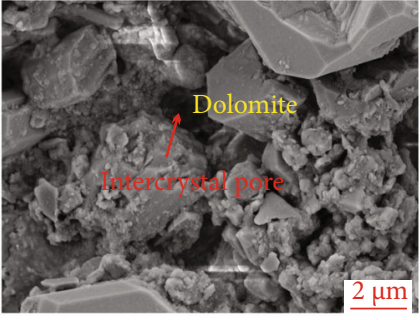

(a)

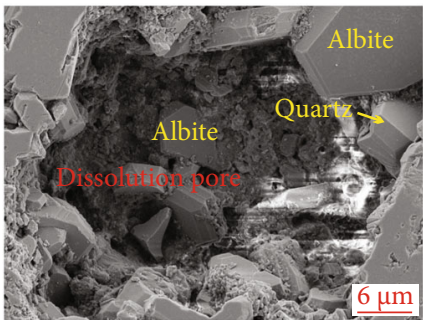

(c)

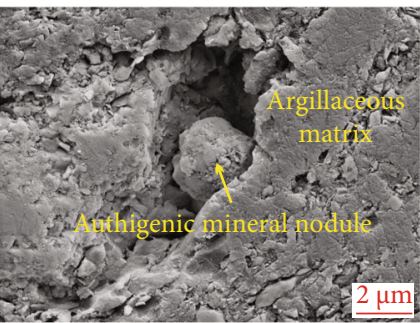

(e)

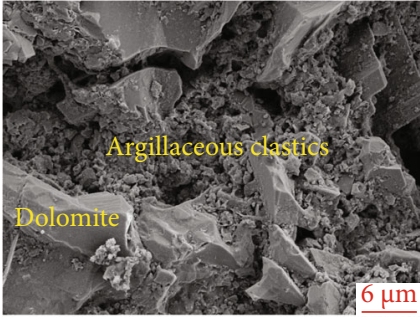

(b)

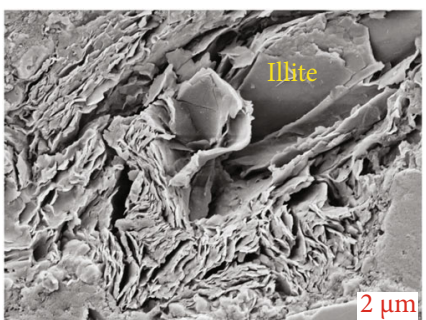

(d)

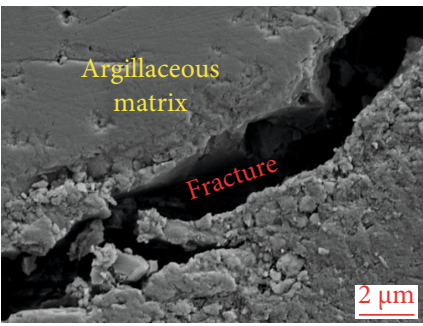

(f)

FIGURE 7: FE-SEM images showing the reservoir space types in the Lucaogou Formation, Jimusar Sag: (a) well J303, 2597.7 m, dolomite with intercrystalline pores; (b) well J305, $3416.8 \mathrm{~m}$, dolomitic mudstone with intergranular pores and dissolution pores; (c) well J10025, $3549.43 \mathrm{~m}$, silty mudstone with dissolution pores; (d) well J43, $2948.5 \mathrm{~m}$, shale with intercrystalline pores between clay minerals (illite); (e) well J10025, $3567.6 \mathrm{~m}$, shale with intergranular pores and dissolution pores and authigenic mineral nodules; (f) well J303, $2597.7 \mathrm{~m}$, dolomite with fractures.

developed in the dolomites, and bedding cracks are more widespread in the mudstones.

(2) FE-SEM Images. On the basis of thin section observations above, four types of reservoir space were further investigated using FE-SEM images, including fractures and intergranular, intercrystalline, and dissolution pores. The intergranular and intercrystalline pores are primary pores, whereas the dissolution pores and fractures are secondary reservoir space (Figure 7).

The primary pores in the Lucaogou Formation are widely developed in the carbonate rocks, mudstones, and siltstones and have various shapes (Figures $7(\mathrm{a}), 7(\mathrm{~b}), 7(\mathrm{~d})$, and $7(\mathrm{e})$ ). Intercrystalline pores in dolomites are the most important primary intercrystalline pores, and the pore size is mostly between tens and hundreds of nanometers (Figure 7(a)). Intercrystalline pores between clay minerals are also generally developed. Mixed layers of illite-montmorillonite and illite are the main clay minerals of the Lucaogou Formation. The illite is mostly flaky. The intercrystalline pores range in size from tens to hundreds of nanometers and exhibit good connectivity (Figure $7(\mathrm{~d})$ ). The intergranular pores are contact pores between mineral grains (Figures $7(\mathrm{~b})$ and $7(\mathrm{e})$ ). The pore size varies greatly, and these pores occur mostly in the muddy matrix, such as at the contacts between quartz and clay minerals and between carbonate and other minerals as well.

The secondary pores are widely developed in the carbonate rocks and mudstones and occur mostly in dolomite, calcite, quartz, and feldspar minerals (Figures 7(b), 7(c), 7(e), and $7(f))$. The pore size ranges from a few nanometers to a few microns. The secondary pores formed mainly due to dissolution during diagenesis.

In summary, the reservoir space in the Lucaogou Formation includes structural-diagenetic fractures and intergranular, intercrystalline, intragranular, and dissolution pores. Intercrystalline pores are mainly developed in the dolomites, and dissolution pores are mostly developed in the siltstones and carbonate rocks. Structural-diagenetic fractures are mostly developed in the mudstones.

4.4.2. Pore Size Distribution. Most of the pore size distribution curves for the Lucaogou Formation shale sequence exhibit one or two peaks, and a few samples have three peaks. The NMR $T_{2}$ spectra with one peak (Figures 8(a)$8(\mathrm{~d})$ ) are mostly for mudstones and siltstones, suggesting 


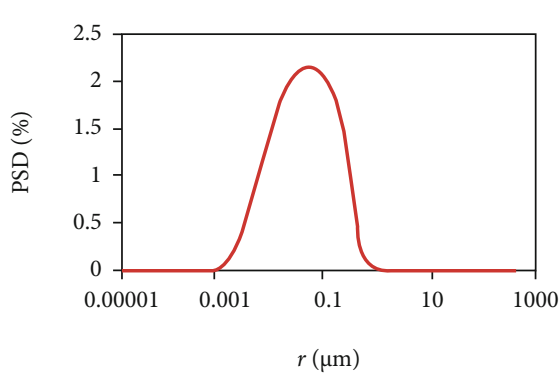

- J-167

(a)

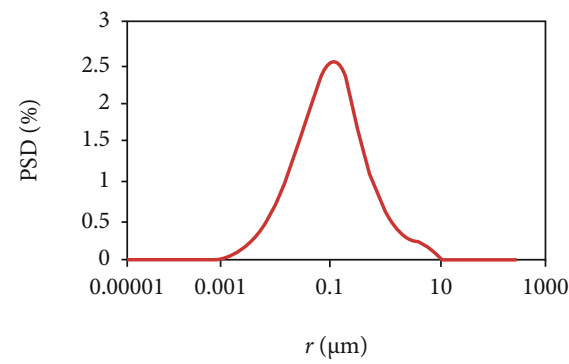

J -131

(c)

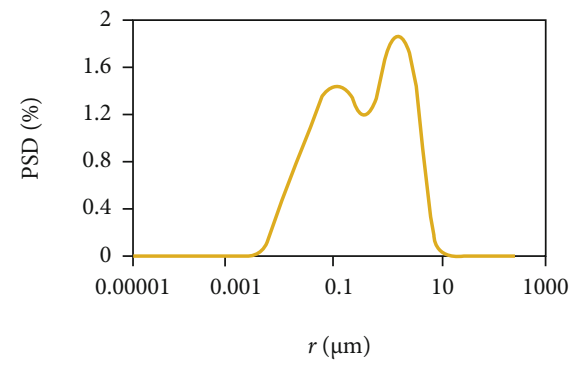

- J-140

(e)

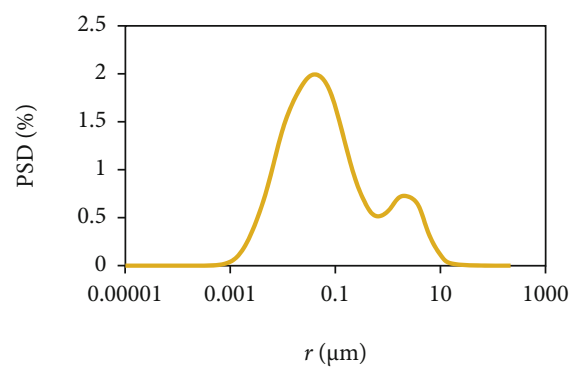

- J-127

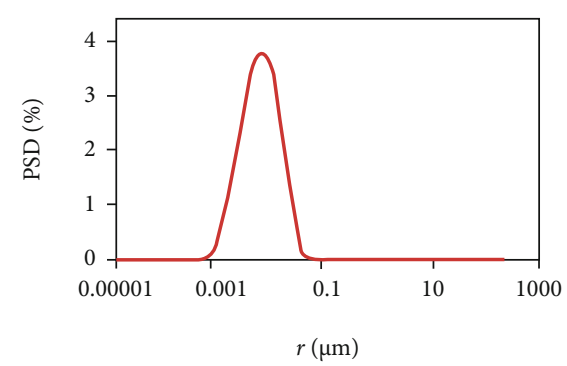

- J-111

(b)

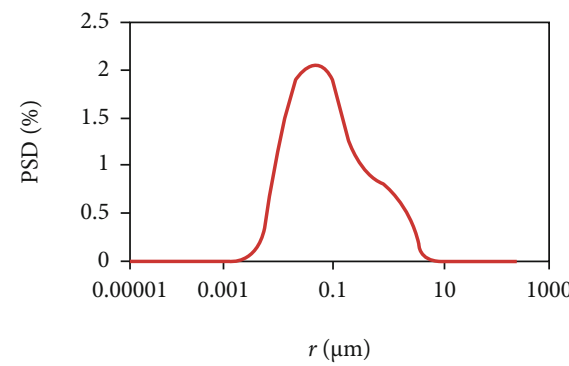

(d)

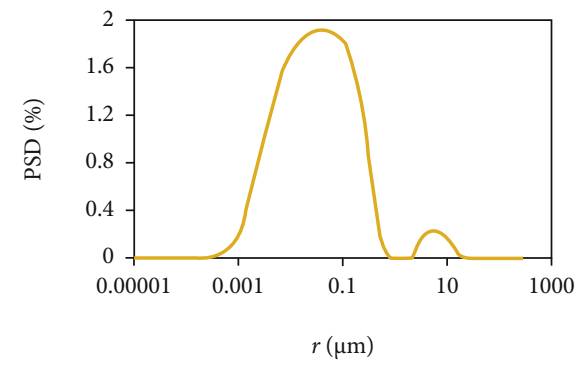

- J-170

(f)

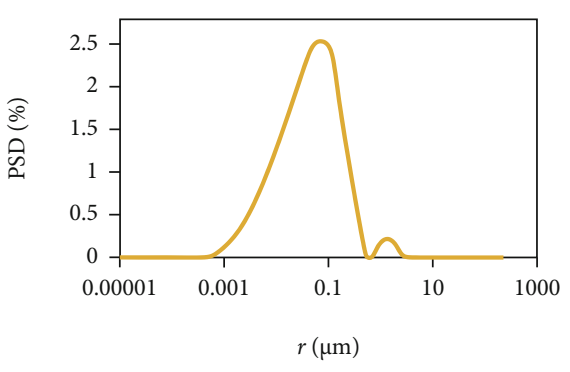

- J-151

(g)
(h)

Figure 8: Continued. 


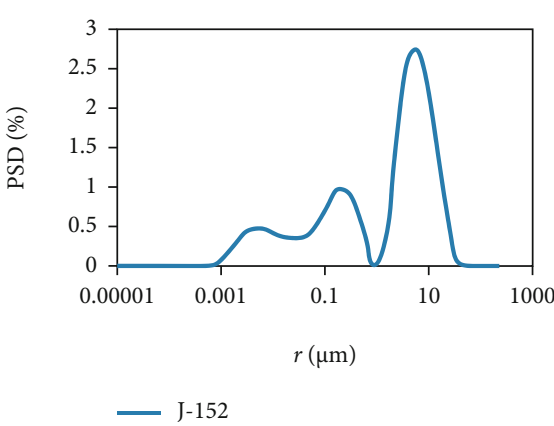

(i)

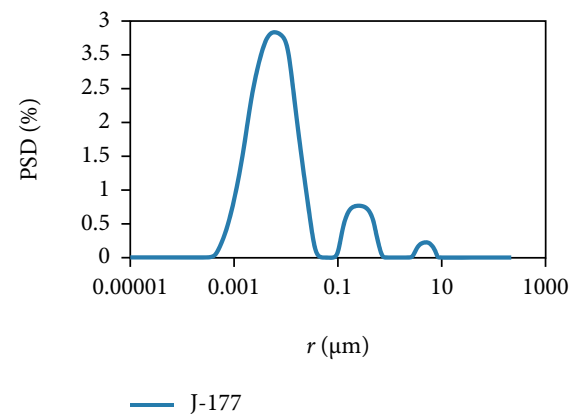

(k)

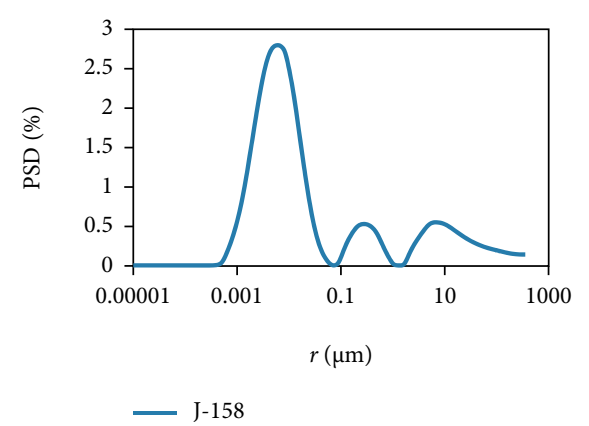

(j)

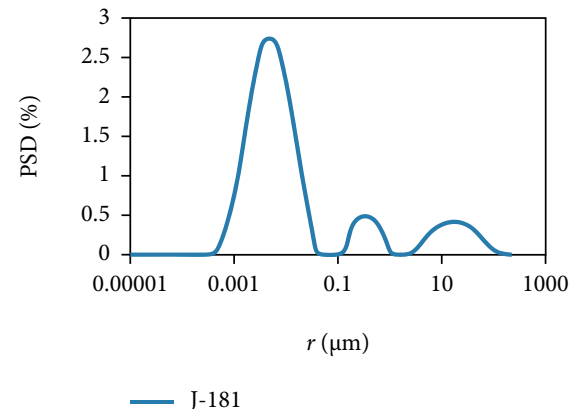

(1)

FIgURE 8: NMR $T_{2}$ spectra of the Lucaogou Formation, Jimusar Sag. (a) Well J10025, 3673.42 m, dolomitic mudstone with abundant organic matter and obvious dolomitization. Nanoscale pores $(<1 \mu \mathrm{m})$ are present with a pore size of $1-100 \mathrm{~nm}$. (b) Well J10025, $3487.21 \mathrm{~m}$, wellsorted dolomitic siltstone containing rounded minerals. Intergranular pores are completely cemented by calcites and dolomites. The strong compaction and cementation have resulted in an extremely small pore size (i.e., nanopores; $<1 \mu \mathrm{m}$ ), with the main pore size range being 1-40 nm. (c) Well J10025, $3537.1 \mathrm{~m}$, dolomitic siltstone with evenly distributed dolomite, feldspar, and quartz. The main pore size range is $0.001-10 \mu \mathrm{m}$. (d) Well J10025, $3506.1 \mathrm{~m}$, mudstone containing a large carbonate vein and cracks. The pore size range is relatively large and consists of nano-micropores with a main pore size range of $0.001-10 \mu \mathrm{m}$. (e) Well J10025, 3559.31 m, laminated dolomitic siltstone containing abundant organic matter and cemented by dolomite and calcite. Micron-sized pores $(>1 \mu \mathrm{m})$ occur, and the main pore size range is $1-10000 \mathrm{~nm}$. (f) Well J10025, $3680.99 \mathrm{~m}$, laminated marlstone containing abundant, small, spherical particles of organic matter. Dissolution and intergranular pores are well developed. Micron-scale pores are present $(>1 \mu \mathrm{m})$, and the main pore size ranges are $1-800 \mathrm{~nm}$ and $2-15 \mu \mathrm{m}$. (g) Well J10025, $3531.33 \mathrm{~m}$, silty dolomite with bioclastic layers. Dissolution pores that are micron-sized $(>1 \mu \mathrm{m})$ are present, and the main pore size range is $0.001-12 \mu \mathrm{m}$. (h) Well J10025, 3603.07 m, residual oolitic-micritic dolomite. Most of the concentrically laminated oolites have been dolomitized. Dissolution pores are micron-sized (>1 $\mu \mathrm{m})$, and the main pore size range is $0.001-3 \mu \mathrm{m}$. (i) Well $\mathrm{J} 10025,3608.16 \mathrm{~m}$, silty argillaceous dolomite with lumpy organic matter (fungi-algae lumps). Crustacean-like calcite cement has formed on the surfaces of the fungi-algae. Nano-micron pores are developed, and the main pore size ranges are $1-1000 \mathrm{~nm}$ and $1.5-40 \mu \mathrm{m}$. (j) Well J10025, 3623.82 m, argillaceous siltstone that contains organic-rich layers and oriented silt-sized minerals. Nano-micron pores occur, with main pore size ranges of $1-1000 \mathrm{~nm}, 1.5-40 \mu \mathrm{m}$, and $100-200 \mu \mathrm{m}$. (k) Well J10025, $3700.88 \mathrm{~m}$, laminated silty dolomitic mudstone. Nano-micron pores have main pore size ranges of $1-50 \mathrm{~nm}, 150-800 \mu \mathrm{m}$, and $1-10 \mu \mathrm{m}$. (l) Well J10025, $3713.18 \mathrm{~m}$, mudstone containing large mineral veins and crystalline pyrite. Nano-micron pores have main pore sizes ranges of $1-60 \mathrm{~nm}$ and $0.1-200 \mu \mathrm{m}$.

that both are well sorted. The mudstones contain mostly nanoscale pores, and the siltstones have a wide pore size distribution, which has been strongly affected by diagenesis. The NMR $T_{2}$ spectra with two peaks (Figures $8(\mathrm{e})-8(\mathrm{~h})$ ) are mostly carbonate rocks and siltstones. The dolomites contain dissolution and intercrystalline pores in dominance; given that silt and tuffaceous materials, such as feldspars, are susceptible to fluid dissolution, the pore size distribution ranges are variable. If the samples are laminated, the left and right peaks are undulating, indicating that there is size heterogeneity for similarly sized pores (Figures $8(\mathrm{e})$ and $8(\mathrm{~g})$ ). The NMR $T_{2}$ spectra with multipeaks $(\geq 3)$ (Figures $8(\mathrm{i})-8(\mathrm{l})$ ) are mostly carbonate rocks and mudstones with multiple components (or large veins); these samples have variable and heterogenous pore size distributions.

In summary, the pore size in the mudstones is mostly nanoscale, whereas in carbonate rocks, it is micron-scale. The main pore size in the siltstone is either nano- or micron-scale, due to the presence of laminae and/or diagenetic veins.

\section{Discussion}

5.1. Shale Oil Potential of Different Lithofacies. The oil saturation index $\left(\mathrm{OSI}=S_{1} \times 100 / \mathrm{TOC}, \mathrm{mg} \mathrm{HC} / \mathrm{g}\right.$ TOC$)$ is commonly used to characterize the shale oil potential and 


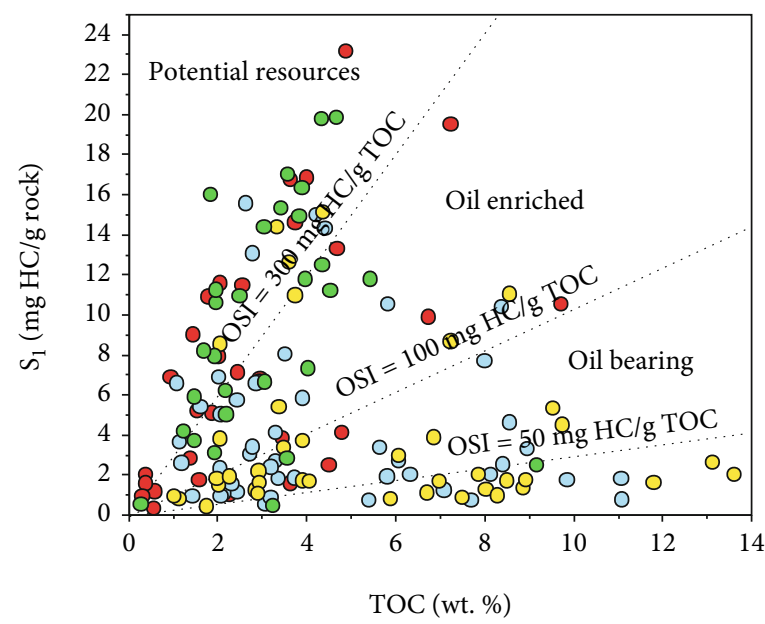

(a)

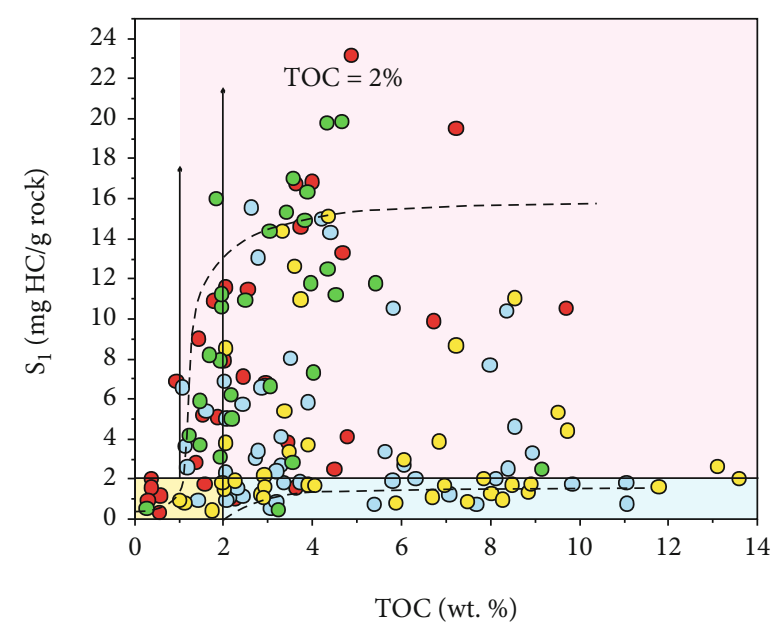
Legend
- Carbonate rock
○ Dolomitic/calcareous mudstone
O Tuffaceous/silty mudstone
O Siltstone

(b)

FIgURE 9: Shale oil potential of different lithofacies in the Lucaogou Formation, Jimusar Sag. (a) $S_{1}$ values versus TOC contents showing the OSI ranges for the different lithofacies. (b) Classification of the shale oil resource potential.

represents the oil content in the rocks $[14,15,18,24,53,54]$. In general, OSI $\geq 100 \mathrm{mg} \mathrm{HC} / \mathrm{g}$ TOC is the threshold for potential economically recoverable shale oil [24].

Figure 9 shows OSI values for the four major types of lithofacies in the Lucaogou Formation. The average OSI value of the carbonate rocks, siltstones, dolomitic/calcareous mudstones, and tuffaceous/silty mudstones is $315.03 \mathrm{mg}$ $\mathrm{HC} / \mathrm{g}$ TOC, $343.27 \mathrm{mg} \mathrm{HC} / \mathrm{g}$ TOC, $161.02 \mathrm{mg} \mathrm{HC/g}$ TOC, and $114.61 \mathrm{mg} \mathrm{HC} / \mathrm{g}$ TOC, respectively. This suggests that the shale oil potential of the different lithofacies in the Lucaogou Formation is generally good, as the average OSI value of all the lithofacies is $\geq 100 \mathrm{mg} \mathrm{HC} / \mathrm{g}$ TOC (i.e., an "oil cross-over" effect). Most of the dolomitic/calcareous and tuffaceous/silty mudstones have relatively low shale oil potential (OSI $=50-100 \mathrm{mg} \mathrm{HC} / \mathrm{g}$ TOC), although some are high-oil-bearing and have shale oil potential. Most of the carbonate rocks and siltstones are oil-rich and have quite a high shale oil potential.

It is proposed that the relationship between the free hydrocarbon content $\left(S_{1}\right)$ of a source rock (i.e., the oil content) and the TOC contents shows a "three-part" trend based on the analyses of main source rocks in petroliferous basins in eastern China [18]. Due to differences in provenance, sedimentary environment, mineralogy, and organic matter, the distinguishing thresholds of the "three-part" trend do not work universally and vary in given source rock units. Compared with the standards suggested, when the TOC $<2$ wt. $\%$ and $S_{1}<2 \mathrm{mg}$ $\mathrm{HC} / \mathrm{g}$ rock for the Lucaogou shales (Figure 9(b)), the organic matter content or thermal evolution of the rock is not high enough for generated hydrocarbons to exceed the saturation of adsorbed hydrocarbons. Under such conditions, it is an invalid resource. When TOC $>2$ wt. $\%$ and $S_{1}<2 \mathrm{mg} \mathrm{HC} / \mathrm{g}$ rock, there are potential shale oil resources in the source rocks. This means although the organic matter content is high, the rock has not yet expelled hydrocarbons due to the low degree of thermal evolution. When TOC $>2 \mathrm{wt} . \%$ and $S_{1}>2 \mathrm{mg}$ $\mathrm{HC} / \mathrm{g}$ rock, the content of free hydrocarbons is higher, and the generated hydrocarbons are likely to meet the adsorption of kerogen and the mineral surfaces and are gradually discharged into the pore and fracture system. At this time, the source rocks are an ideal target for shale oil exploration. It is clear that the Lucaogou Formation has good shale oil potential (Figure 9).

5.2. Factors Controlling Shale Oil Potential and Accumulation. The shale oil content is closely related to its own oil generation and expulsion efficiency $[14,15,17,18]$. When the oil generation is high and the oil expulsion is low, the shale has the highest oil content and thus is conducive for shale oil exploration [13]. However, it should be noted that shale oil may also migrate very short distances and accumulate in adjacent rocks. Thus, when analyzing the factors controlling shale oil potential and accumulation, we evaluate not only its own hydrocarbon generation potential but also the reservoir space, oil occurrence state, and lithofacies associations in a comprehensive perspective as best.

5.2.1. Hydrocarbon Generation Potential. The primary factor that affects the shale oil content of rocks is the ability to generate hydrocarbons, which involves the abundance, type, and maturity of the organic matter $[24,55]$. In the Lucaogou Formation, although carbonate rocks and siltstones have 


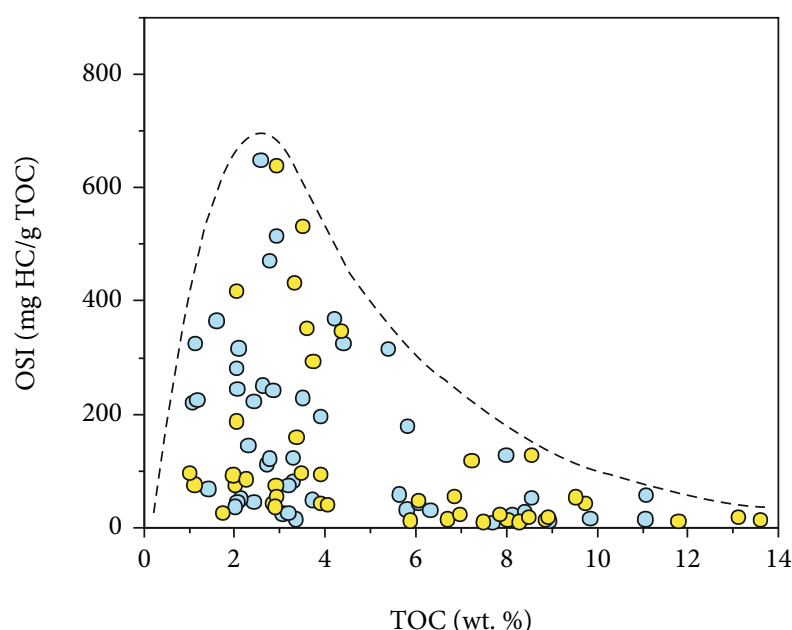

(a)

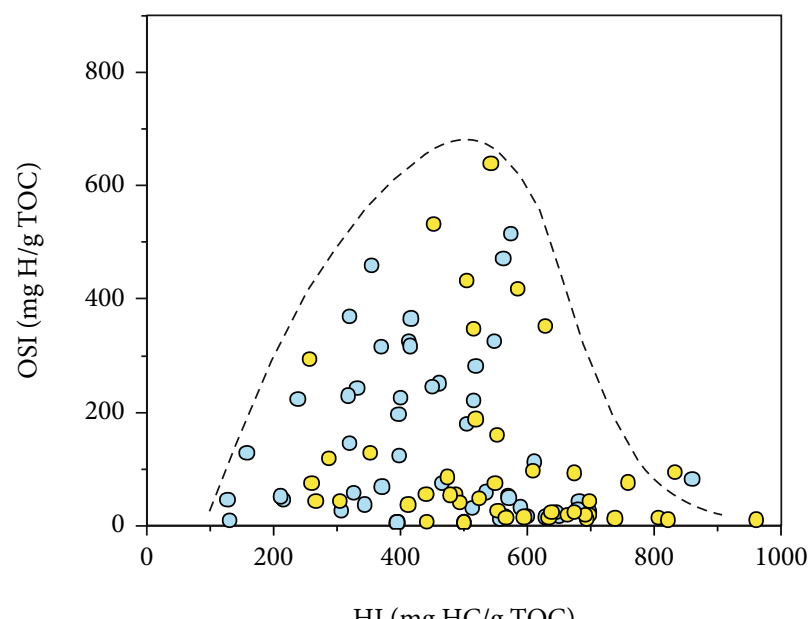

(c)

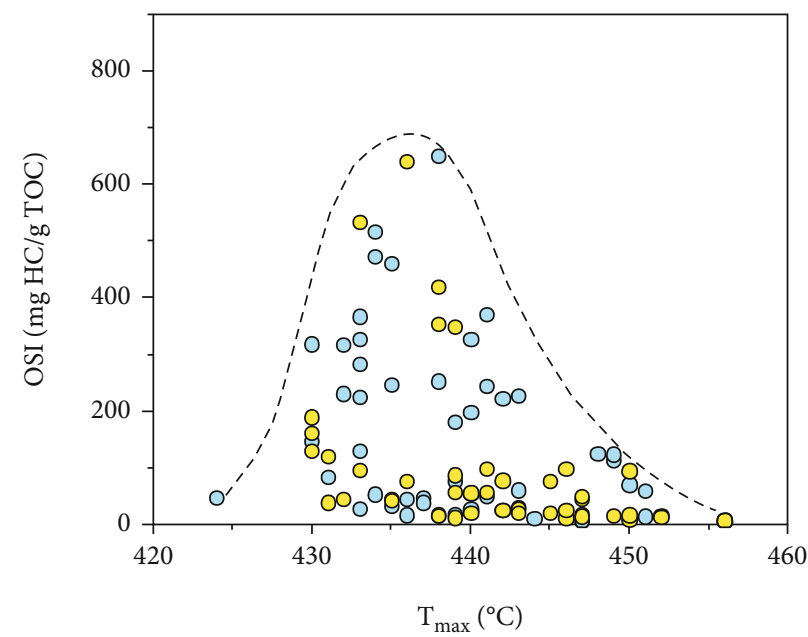

(e)

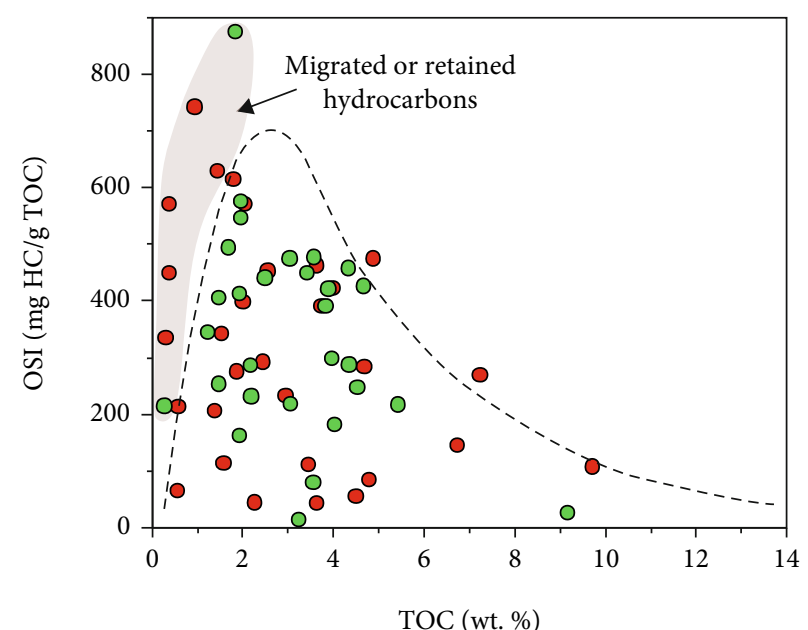

(b)

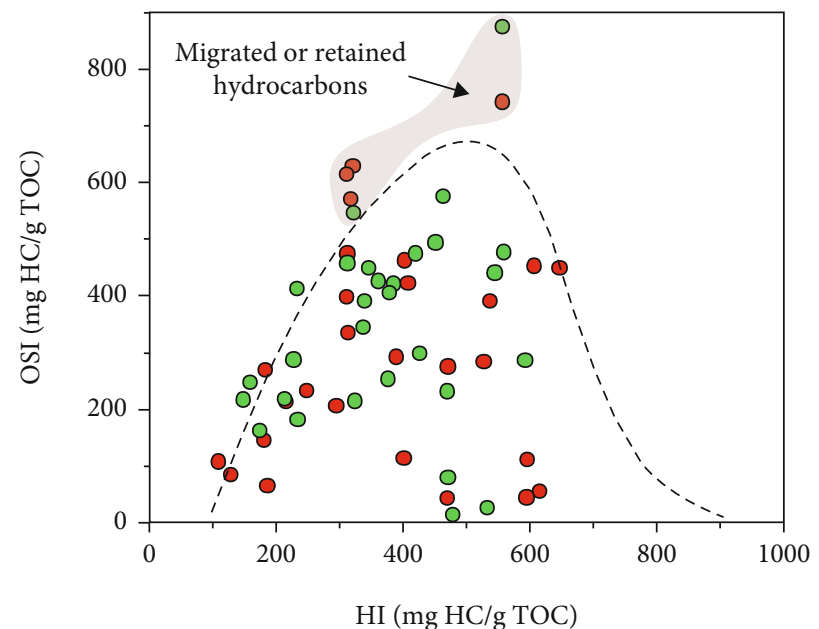

(d)

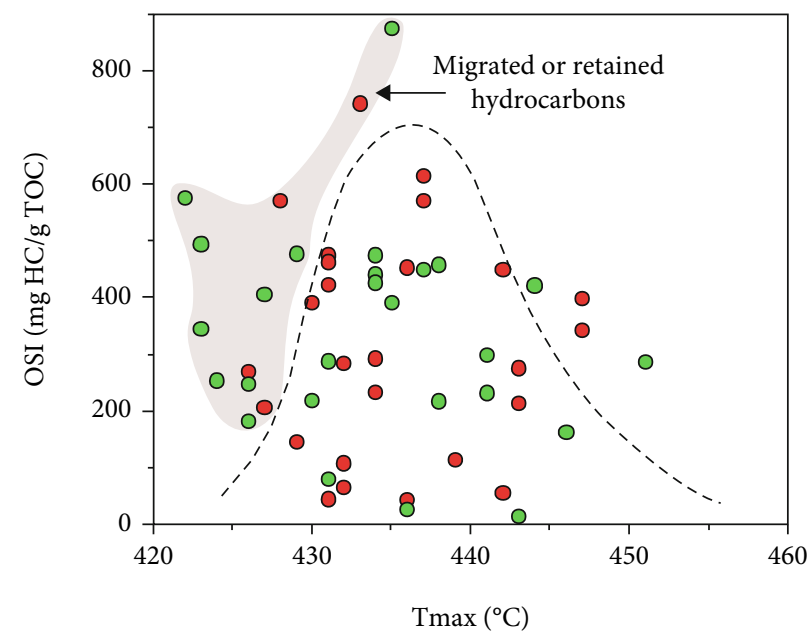

(f)

Figure 10: Continued. 

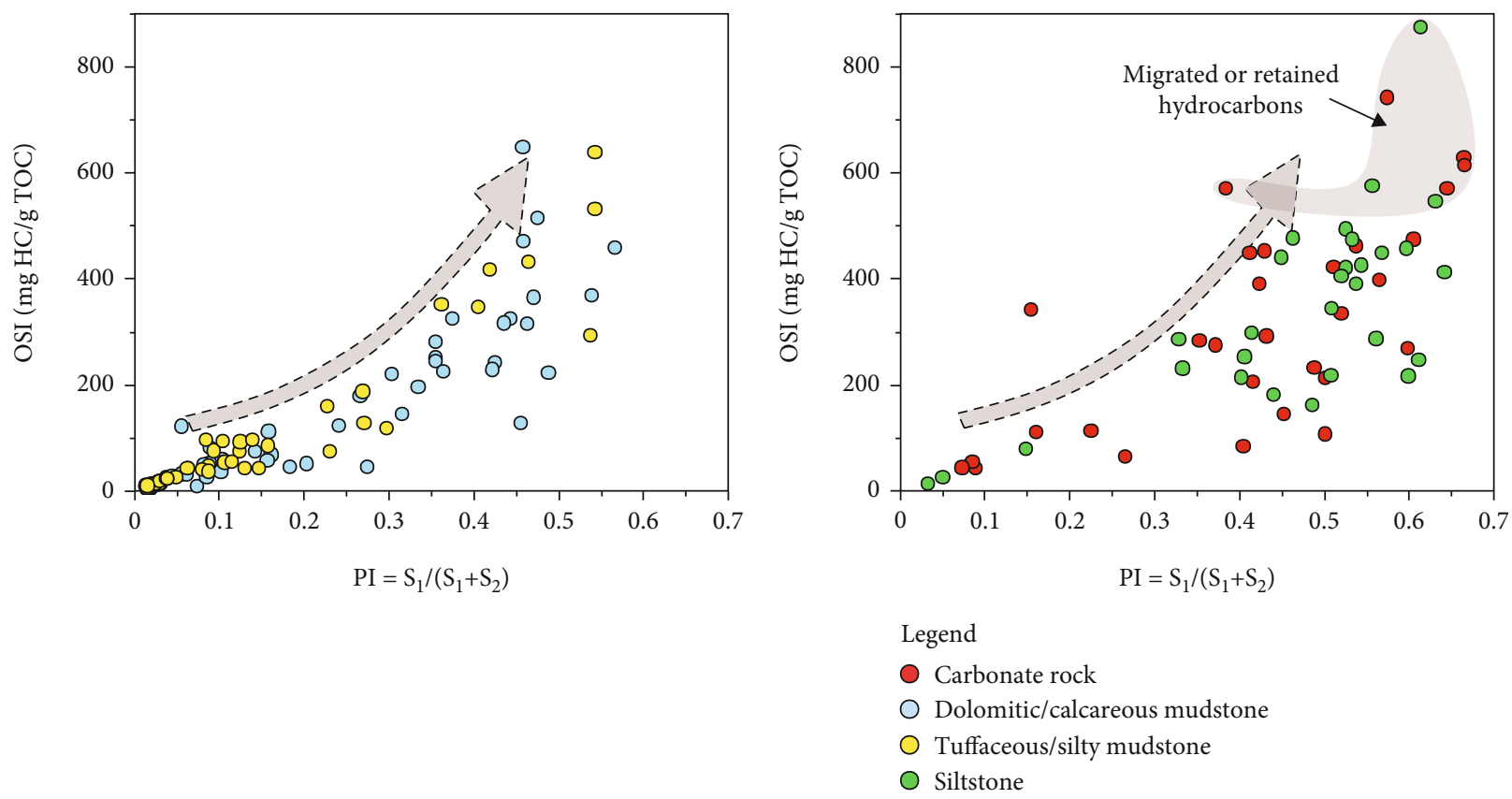

(g)

(h)

Figure 10: Plots of shale oil potential and hydrocarbon generation potential for different lithofacies in the Lucaogou Formation, Jimusar Sag.

hydrocarbon generation potential to certain extents, they are not conventional source rocks. The mudstones have a better hydrocarbon generation potential than these rocks. Therefore, in this study, the mudstones are considered separately from the carbonate rocks and siltstones, in order to assess the correlations between the hydrocarbon generation potential and the shale oil potential (i.e., OSI values) of the highquality source rocks. Results show that the OSI values of the mudstones first increase and then decrease with increasing TOC contents (Figure 10(a)). When the TOC content is close to $2 \mathrm{wt} . \%$, the OSI values reach the highest, indicating that the organic matter in the source rocks has adsorbed hydrocarbons. When the organic matter content is high enough, a large amount of hydrocarbons are adsorbed, resulting in a decrease in the OSI value [56]. The trend envelope of the correlation analysis between the OSI value and the TOC value of mudstone is extrapolated to the carbonate rocks and siltstones (Figure 10(b)), and it is found that the correlation is similar to that of the mudstones. But it is worth noting that when the TOC content is low (<1 wt.\%), some carbonate rocks and siltstones have high OSI values (Figure 10(b)), with a maximum value of $\geq 800 \mathrm{mg} \mathrm{HC/g}$ TOC. These samples have good physical properties and abundant dissolution pores, into which hydrocarbons have migrated nearby, resulting in high $S_{1}$ values.

The HI versus OSI plot shows the relationship between the type of organic matter and the shale oil potential. For the mudstones (Figure 10(c)), the HI value first increases and then decreases. The OSI value reaches the highest when the HI value is about $500 \mathrm{mg} \mathrm{HC} / \mathrm{g}$ TOC. This indicates that when the HI value is high, the type of kerogen tends to be oil-prone at I-
$\mathrm{II}_{1}$. Like the TOC contents, as $\mathrm{HI}$ values increase further (>500 $\mathrm{mg} \mathrm{HC} / \mathrm{g}$ TOC), the OSI values gradually decrease. This suggests that the free hydrocarbons $\left(S_{1}\right)$ may have been expelled, such that the OSI value decreases gradually. The correlation between the OSI and HI values of siltstones and carbonate rocks (Figure 10(d)) seems to be similar to that of the mudstones, but some samples have very high OSI values at low and high HI values (Figure 10(d)). This provides evidence of migration of hydrocarbons in these two lithofacies.

Plots of $T_{\max }$ values versus OSI values can examine the relationship between the thermal evolution of organic matter and the shale oil potential (Figures $10(\mathrm{e})$ and $10(\mathrm{f})$ ). The $T_{\max }$ corresponding to the maximum OSI value for the mudstones in the Lucaogou Formation is about $435^{\circ} \mathrm{C}$ (Figure $10(\mathrm{e})$ ). When the organic matter maturity further increases, a large amount of hydrocarbons are expelled, resulting in a decrease in the OSI values. For the siltstones and carbonates, some samples have significantly lower $T_{\max }$ values at very high OSI values (182.93-876.85 mg HC/g TOC) (Figure 10(f)). This suggests that a large amount of soluble organic matter has migrated into the rocks and that the cracking of the heavy components in the soluble organic matter lowers the $T_{\max }$ values $[57,58]$. Therefore, the $T_{\max }$ values of the mudstones better reflect the relationship between the source rock maturity and the OSI values. When the $T_{\max }$ value is about $435^{\circ} \mathrm{C}$ (roughly equal to $R_{\mathrm{o}}$ value at $0.8 \%$ ), shale oil has its highest potential (Figure $10(\mathrm{e})$ ), which corresponds to the peak of oil generation [52].

In addition, the source rock productivity index (PI $\left.=S_{1} /\left[S_{1}+S_{2}\right]\right)$ exhibits an obvious positive correlation with OSI values (Figures $10(\mathrm{~g})$ and $10(\mathrm{~h})$ ). This indicates that when the source rock has a relatively high proportion of free 

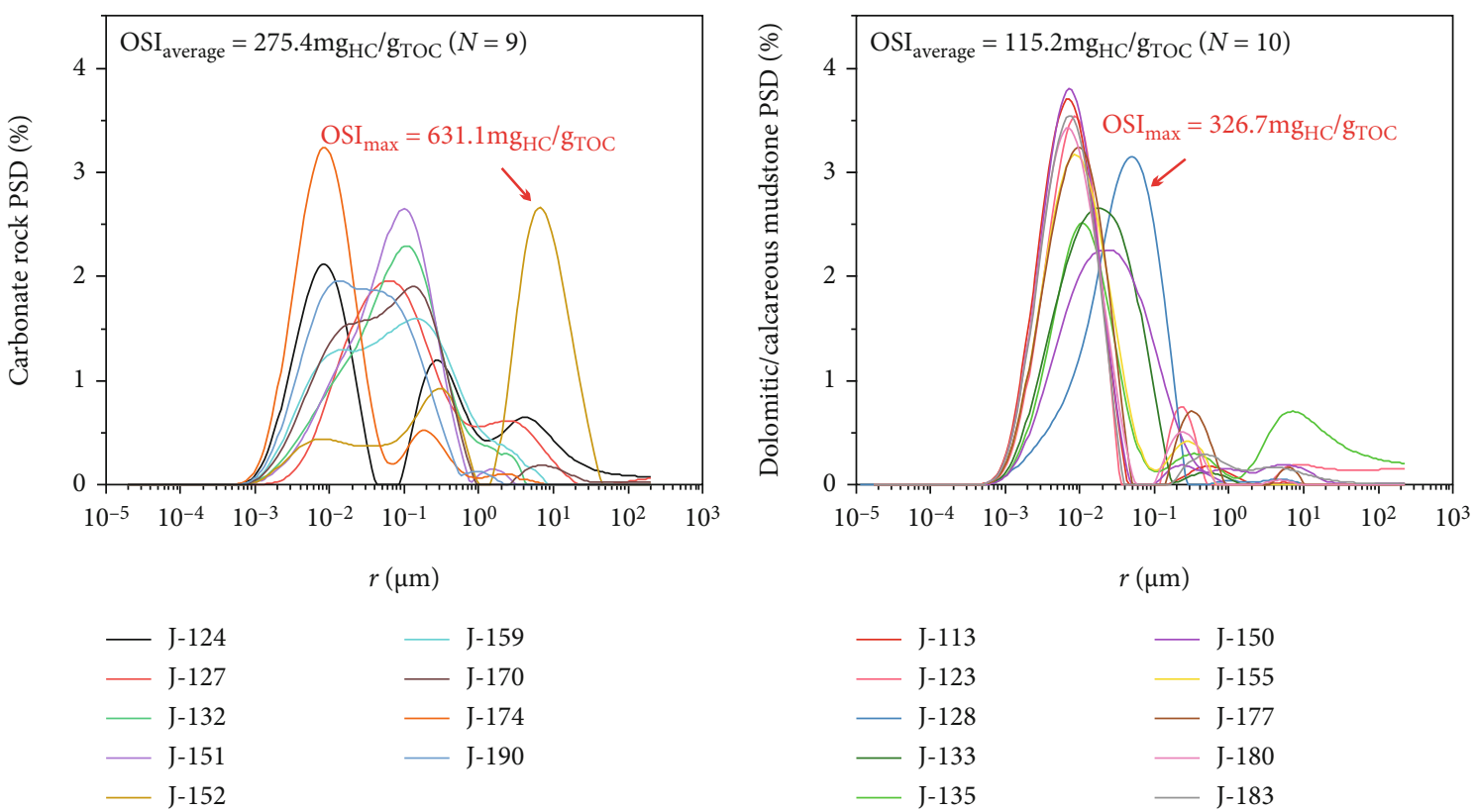

(a)

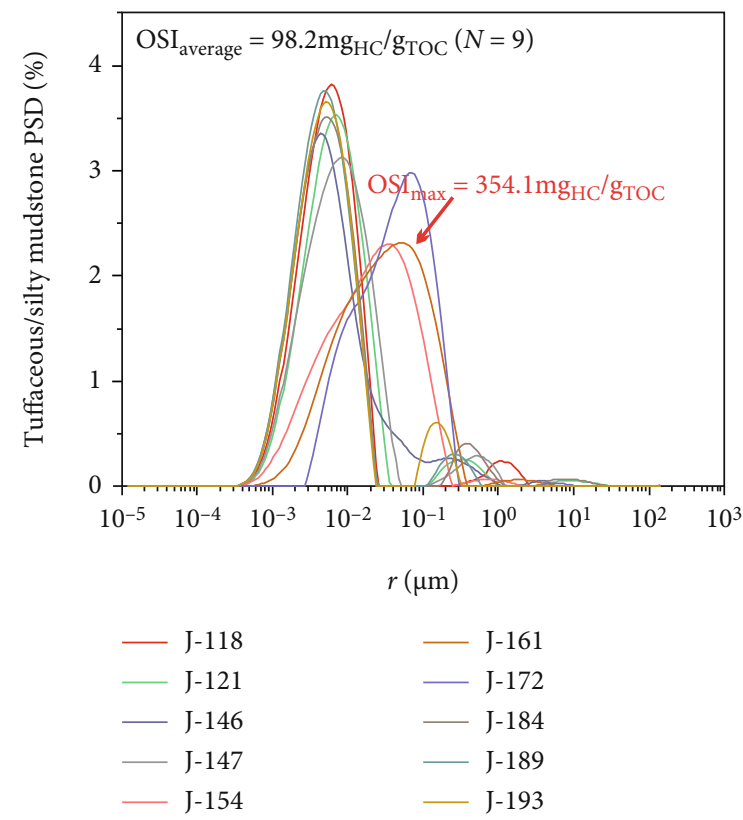

(b)

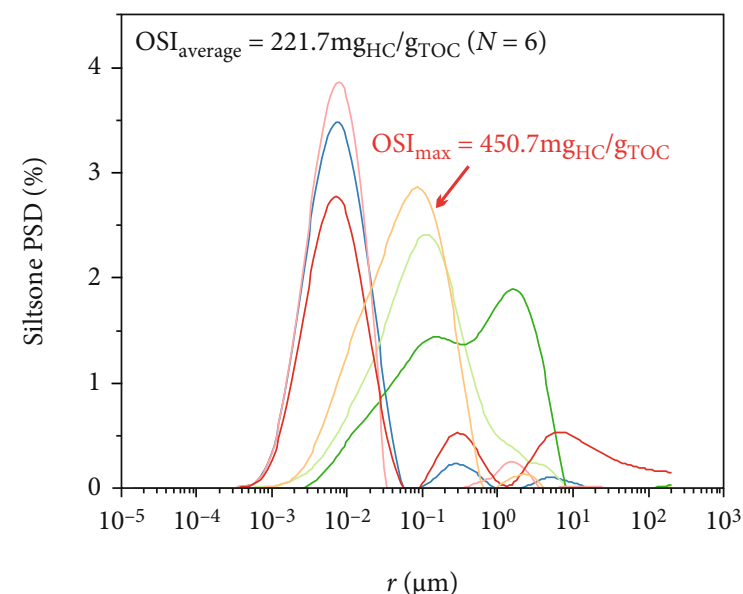

(c)

(d)

FIGURE 11: NMR $T_{2}$ spectra for different lithofacies in the Lucaogou Formation, Jimusar Sag. Pore size distributions in (a) carbonate rocks, (b) dolomitic/calcareous mudstones, (c) tuffaceous/silty mudstones, and (d) siltstones.

hydrocarbons (as compared to a higher content of adsorbed hydrocarbons), there is good shale oil potential. The PI and OSI values of some siltstones and carbonate rocks are extremely high, which correspond with high $\mathrm{HI}$ and low $T_{\max }$ and $R_{\mathrm{o}}$ values. This further corroborates that the carbonate rocks and siltstones were more susceptible to hydrocarbon migration than the mudstones as discussed above.

In summary, when assessing the effects of hydrocarbon generation conditions on the shale oil potential and accumula- tion of the Lucaogou Formation, the mudstones should be mainly considered. When the shale oil potential of the Lucaogou Formation is optimal, the corresponding source rock conditions are as follows: TOC $\approx 2 \mathrm{wt} . \%, \mathrm{HI} \approx 500 \mathrm{mg} \mathrm{HC} / \mathrm{g}$ TOC, and $T_{\max } \approx 435^{\circ} \mathrm{C}$ (Figures $10(\mathrm{a}), 10(\mathrm{c})$, and $10(\mathrm{e})$ ).

5.2.2. Reservoir Space. Bedding and structural fractures, pressure solution stylolites, and other micro-nanopore throats are widely developed in shale reservoir systems, which form 


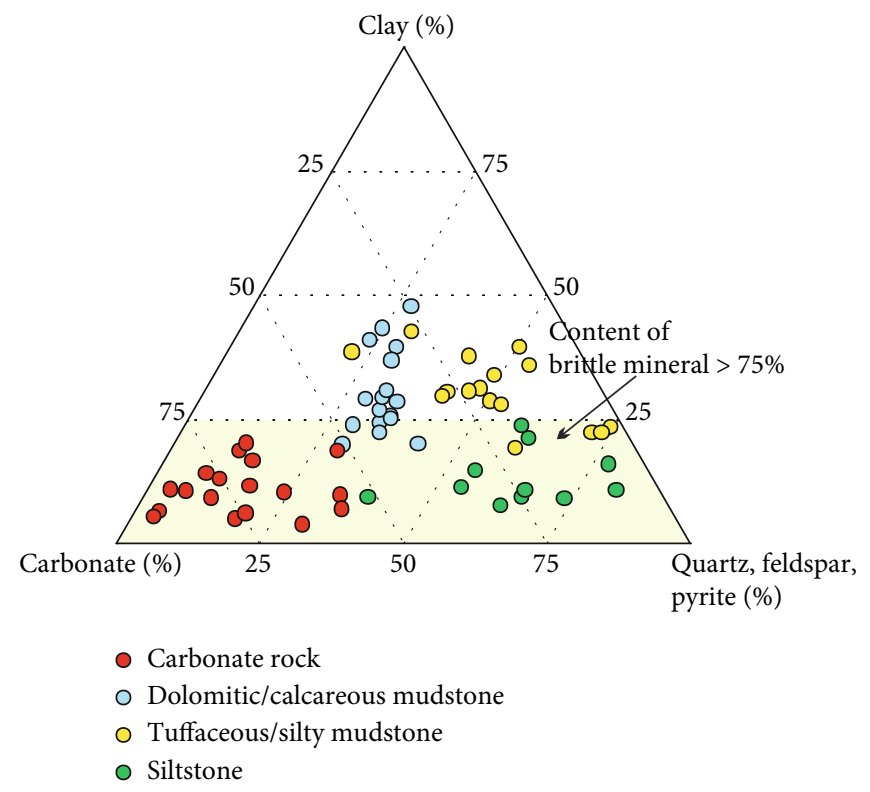

FIGURE 12: Ternary diagram showing the mineralogy of the different lithofacies in the Lucaogou Formation, Jimusar Sag.

the migration channels and storage space for movable oil and the basis for continuous large accumulations of oil and gas. This determines whether shale oil can be exploited on a large scale $[29,35,59,60]$. Previous studies have shown that the physical properties of rocks in the Lucaogou Formation have a control on whether they are oil-bearing [61]. However, the specific characteristics and controlling mechanisms of the different lithologies are still not entirely clear.

The NMR results for the four major types of lithofacies in this study show that the physical characteristics of the lithologies are quite different (Figure 11). The pore size distributions of the mudstones are mostly in the high-amplitude unimodal or weakly bimodal; the pore size of the main peak is small, and micron-scale pores are rare (Figures 11(b) and 11(c)). However, the siltstones and carbonate rocks mostly have wide low-amplitude unimodal and weakly bimodal distributions; the main peak pore size is large, and the pore size distribution is wide (Figures 11(a) and 11(d)), which has a good correspondence with a high shale oil potential. This reflects a certain correlation between petrophysical properties and shale oil potential. In particular, sample J-152 is a silt-bearing argillaceous dolomite with $\mathrm{TOC}=1.43 \mathrm{wt} . \%$ and the highest OSI value (631.1 mg HC/g TOC) of the measured carbonate rock samples. The main peak of its pore size distribution is narrow with abundant micropores $(1-100 \mu \mathrm{m})$ (Figure $11(\mathrm{a}))$. This suggests the effects of rock physical properties on shale oil contents.

Petrophysical properties are closely related to the mineralogy of rocks, including fracture development, brittleness, and seepage migration. As such, mineralogy has controls on shale oil enrichment $[3,13]$. In this study, mudstones in the Lucaogou Formation generally have a good shale oil potential (OSI average $>100 \mathrm{mg} \mathrm{HC} / \mathrm{g}$ TOC). Comparatively, the carbonate rocks and siltstones have much higher OSI values, which are consistent with the higher content of brittle minerals in these rocks (Figure 12). When the content of brittle minerals is high, and due to their larger grain size than clay minerals, more larger-intergranular pores are easily formed, which improves the rock physical properties [13]. In addition, brittle minerals, such as carbonates and feldspars, are easily corroded by organic acids discharged during the evolution of organic matter, which forms dissolution pores. The evolution of organic matter also promotes recrystallization, which causes dolomite and calcite to recrystallize and increases the abundance of intercrystalline pores. When the content of brittle minerals increases, the rock brittleness also increases, and fractures are easily generated. These factors all further increase the reservoir storage spaces [25].

In addition, where the laminae develop, especially organic laminae that alternate with carbonate or silty laminae, organic acids will dissolve the carbonate and silty laminae, thereby forming dissolution cracks $[62,63]$. For example, sample J128 is a dolomitic mudstone with silt laminae and the interaction with organic matter has resulted in good physical properties (Figure 11(c)). This has increased its permeability, which is conducive to shale oil enrichment. Therefore, the relationship between reservoir physical properties and OSI values is essentially controlled by the lithofacies, because the mineralogy and structure of each lithofacies have different physical properties, which further control the shale oil content.

In summary, the Lucaogou Formation comprises a set of mixed fine-grained deposits of dark mud, silty sands, and carbonates that were deposited in a saline lacustrine basin. Mudstones have generated hydrocarbons, and carbonate rocks and siltstones have relatively better physical properties due to the presence of brittle minerals and laminae that act as reservoirs. Compared with the mudstones, the carbonate rocks and siltstones have a better shale oil potential, 


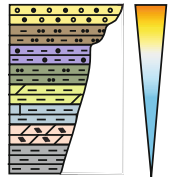

(a) Facies mixing

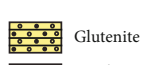

\begin{tabular}{lll}
$0-\cdots$ & Sandy \\
\hdashline$-\therefore$ & mudstone
\end{tabular}

政 Silty

Dolomitic

mudstone

Calcareous
mudstone

-

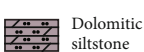
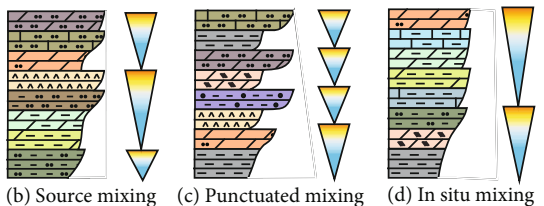

(b) Source mixing

(c) Punctuated mixing

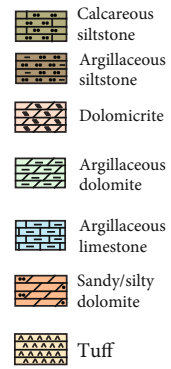

FIgURE 13: Main mixing processes and lithofacies associations of the Lucaogou Formation, Jimusar Sag.

reflecting the controls of lithology and physical properties on shale oil potential. A larger storage space is conducive to the flow and migration of free hydrocarbons. Therefore, the carbonate rocks and siltstones have better oil-bearing properties. The source and reservoir assemblages of the Lucaogou Formation cover a wide area of thin interbedded stratigraphic distribution, which has facilitated the continuous and effective charging and accumulation of shale oil.

\subsection{Multisource Mixed Deposits and Shale Oil Potential.} Compared with the OSI values of shale oil in other saline lacustrine basins in China, such as the Ordos Basin, Songliao Basin, Dongpu Sag, and Jiyang Depression [14, 15, 64-67], almost all the lithofacies in the Lucaogou Formation have good shale oil potential. Moreover, previous studies have also revealed that the source rocks in the Lucaogou Formation are laterally continuous over a large area and that source rocks and reservoirs coexist $[58,68]$. Therefore, for the Lucaogou Formation, it is necessary to examine combinations of the different lithofacies to better assess the contribution of the source-reservoir system of different mixing processes to shale oil productivity.

Based on the study of Mount [69], there are four types of mixing processes, including "facies mixing, source mixing, punctuated mixing, and in situ mixing" in the mixed rock sequences [69-74]. In the Lucaogou Formation, there was not only mixing between terrigenous materials and intrabasinal carbonates but also different degrees of mixing with volcanic materials (Figure 13).

Facies mixing occurs mainly at the transition zone between different sedimentary facies where carbonate rocks are interbedded with clastic rocks. In most cases, the sedimentary sequence shows a gradual change with water depth (Figure 13(a)). Source mixing is caused by the erosion of the adjacent carbonate source area, which provides carbonate components that can then mix with clastic sediments. Source mixing is controlled by structural factors, such as faults and steep topography. Vertically, multiple parasequences are superimposed (Figure 13(b)). Punctuated mixing is caused by intermittent high-intensity events. For example, storms can transport and result in abrupt mixing of materials from very different lithofacies. This type of mixing is largely random, and the sequence boundaries in the mixed systems are mostly lithofacies disruption surfaces (Figure 13(c)). In situ mixing is the mixing of calcareous organisms that almost died in situ or nearby to areas of siliceous clastic sedimentation; i.e., the carbonate components are accumulated on the basement of clays and terrigenous clastic rocks (Figure 13(d)).

To evaluate the control of such mixing processes on shale oil accumulation, we compare the TOC contents, average OSI values, and daily oil production with their sedimentary mixing types (Figure 14, Table 2). It can be seen that a good source rock-reservoir combination and high OSI value correspond well to daily oil production. Meaningfully, the sequence with high daily oil production is generally in the patterns of source mixing and in situ mixing. To sum up, the Lucaogou Formation has limited water body circulation and terrigenous input, intercalated with extensive deposition of carbonate rocks and intermittent volcanic materials. It is characterized by fine grain size, variable lithofacies, and frequent thin interbedded layers. Many factors, such as climate, provenance, and hydrodynamic conditions, control the development of different mixing processes in various sedimentary facies zones (Figure 15). Different lithofacies associations control the generation and storage assemblages of shale oil, indicating that the type of sedimentary mixing processes is one of the critical mechanisms of shale oil "sweet spots." The closer to the terrigenous source, the more the development of the sand bodies, which have favorable reservoir properties. However, these areas are far from the source rocks, and thus, the rocks here have weak hydrocarbon generation capacities, which is unconducive for shale oil enrichment. Therefore, the mixing areas between the center of the lake and the terrigenous provenance are most favorable for shale oil accumulation, i.e., the areas of facies mixing and in situ mixing (source mixing on conditions) (Figure 15). Such areas are adjacent to high-quality mudstone source rocks and carbonate and siltstone reservoirs. The results of shale oil production have corroborated this model (Figures 14 and 15). 


\begin{tabular}{|c|c|c|c|c|c|c|c|c|}
\hline $\begin{array}{l}\text { Lithofacies } \\
\text { associations }\end{array}$ & 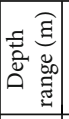 & $\begin{array}{c}\text { OSI }_{\text {average }} \\
(\mathrm{mg} / \mathrm{g}) \\
100 \quad 200 \quad 300 \quad 400 \\
100\end{array}$ & 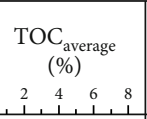 & $\begin{array}{l}\text { Reservoir } \\
\text { property }\end{array}$ & $\begin{array}{l}\text { Well and } \\
\text { position }\end{array}$ & $\begin{array}{l}\text { Mixing process } \\
\text { and environment }\end{array}$ & $\begin{array}{c}\text { Producti } \\
\text {-on } \\
\text { method }\end{array}$ & $\begin{array}{r}\text { Daily oil } \\
\text { output (t) }\end{array}$ \\
\hline 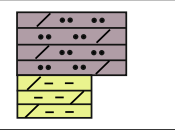 & 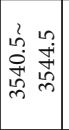 & & & $\begin{array}{l}\text { Fractures, } \\
\text { bedding fractures, } \\
\text { dissolution pores. }\end{array}$ & 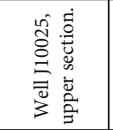 & $\begin{array}{l}\text { Shallow lake, } \\
\text { semi-deep lake and } \\
\text { beach bar. } \\
\text { Source mixing. }\end{array}$ & Flowing & $12.55 \mathrm{t}$ \\
\hline 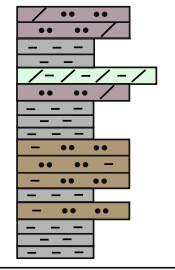 & 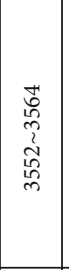 & 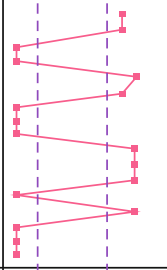 & & $\begin{array}{l}\text { Fractures, } \\
\text { bedding fractures, } \\
\text { dissolution pores. } \\
\\
\text { The silty lamina } \\
\text { contains intergra } \\
\text {-nular pores. }\end{array}$ & 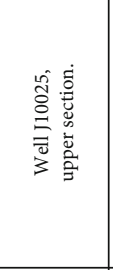 & $\begin{array}{l}\text { Shallow lake and } \\
\text { beach bar. } \\
\text { Shallow lake and } \\
\text { beach bar. } \\
\text { Source mixing and } \\
\text { in-situ mixing. }\end{array}$ & Flowing & $12.53 \mathrm{t}$ \\
\hline 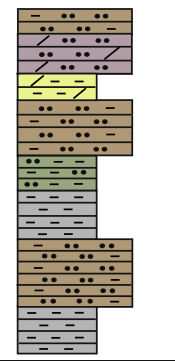 & 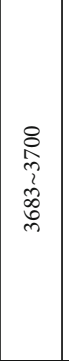 & 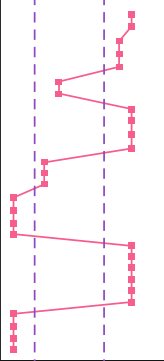 & & \begin{tabular}{|l|} 
Fractures, \\
stylolites, \\
bedding fractures, \\
and dissolution \\
pores. \\
\\
The silty lamina \\
contains intergra \\
-nular pores.
\end{tabular} & 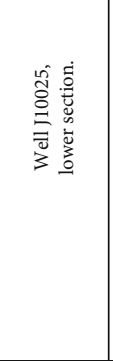 & $\begin{array}{l}\text { Shore to shallow } \\
\text { lake, delta front and } \\
\text { beach bar. } \\
\text { Facies mixing, } \\
\text { source mixing and } \\
\text { partly in-situ } \\
\text { mixing. }\end{array}$ & Swabbing & $6.37 \mathrm{t}$ \\
\hline 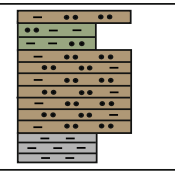 & 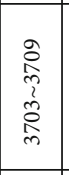 & 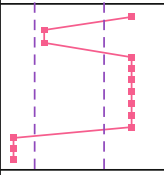 & & \begin{tabular}{|l|}
$\begin{array}{l}\text { Fractures and } \\
\text { dissolution pores. }\end{array}$ \\
The silty lamina \\
contains intergra \\
-nular pores. \\
\end{tabular} & 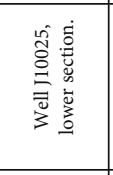 & $\begin{array}{l}\text { Shallow lake and } \\
\text { beach bar. } \\
\text { Facies mixing and } \\
\text { non-mixing. }\end{array}$ & Swabbing & $5.12 \mathrm{t}$ \\
\hline 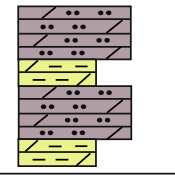 & 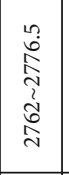 & & & $\begin{array}{l}\text { Fractures, } \\
\text { dissolution pores } \\
\text { and intergranular } \\
\text { pores. }\end{array}$ & 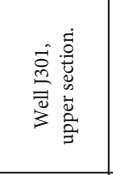 & $\begin{array}{l}\text { Shallow lake to } \\
\text { semi-deep lake. } \\
\text { Facies mixing and } \\
\text { in-situ mixing. }\end{array}$ & Flowing & $9.53 \mathrm{t}$ \\
\hline 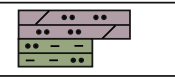 & 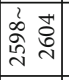 & & & Dissolution pores. & $\begin{array}{l}\begin{array}{l}\text { Well J303, } \\
\text { upper } \\
\text { section. }\end{array} \\
\end{array}$ & $\begin{array}{l}\text { Shallow lake. } \\
\text { punctuated mixing. }\end{array}$ & Swabbing & $4.69 \mathrm{t}$ \\
\hline 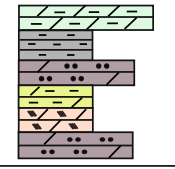 & 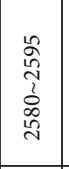 & 1 & & $\begin{array}{l}\text { Fractures, } \\
\text { bedding cracks, } \\
\text { dissolution pores } \\
\text { and intergranular } \\
\text { pores. }\end{array}$ & 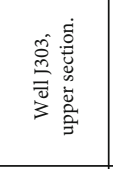 & $\begin{array}{l}\text { Shallow lake, semi- } \\
\text { deep lake to deep } \\
\text { lake. } \\
\text { Facies mixing and } \\
\text { in-situ mixing. }\end{array}$ & Swabbing & $4.48 \mathrm{t}$ \\
\hline 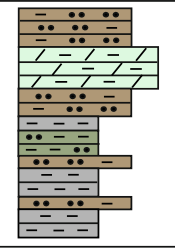 & 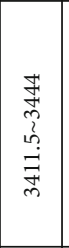 & $\frac{1}{12}$ & & \begin{tabular}{|l}
$\begin{array}{l}\text { Fractures, } \\
\text { bedding cracks, } \\
\text { dissolution pores. }\end{array}$ \\
The silty lamina \\
contains intergra \\
-nular pores.
\end{tabular} & 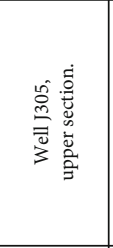 & $\begin{array}{l}\text { Shallow lake, } \\
\text { dolomitic flat and } \\
\text { beach bar. } \\
\text { Facies mixing and } \\
\text { in-situ mixing. }\end{array}$ & Flowing & $18.21 \mathrm{t}$ \\
\hline 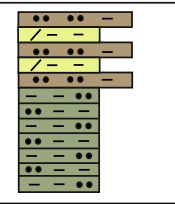 & 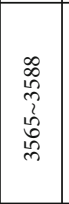 & 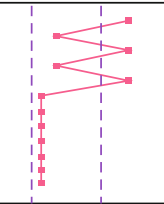 & & $\begin{array}{l}\begin{array}{l}\text { Fractures, } \\
\text { bedding cracks, } \\
\text { dissolution pores. }\end{array} \\
\text { The silty lamina } \\
\text { contains intergra } \\
\text {-nular pores. }\end{array}$ & 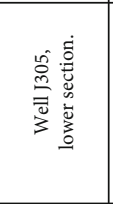 & $\begin{array}{l}\text { Shore to shallow } \\
\text { lake, delta front and } \\
\text { beach bar. } \\
\text { Punctuated mixing. }\end{array}$ & Flowing & $5.76 \mathrm{t}$ \\
\hline
\end{tabular}

FIGURE 14: Comprehensive analysis of the mixing processes, lithofacies associations, and production methods in the high-yield sections of the Lucaogou Formation, Jimusar Sag. 
TABle 2: Average TOC contents and OSI values of the main lithofacies in the sweet spots in the Lucaogou Formation, Jimusar Sag.

\begin{tabular}{lccccc}
\hline Main lithology & TOC $_{\text {average }}($ wt.\% $)$ & $\begin{array}{c}\text { OSI }_{\text {average }} \\
(\mathrm{mg} \mathrm{HC} / \mathrm{g} \mathrm{TOC})\end{array}$ & Main lithology & TOC $_{\text {average }}($ wt.\%) & $\begin{array}{c}\text { OSI }_{\text {average }} \\
(\mathrm{mg} \text { HC/g TOC) }\end{array}$ \\
\hline Argillaceous limestone & 3.75 & 452.01 & Dolomitic siltstone & 3.23 & 334.98 \\
Argillaceous dolomite & 1.87 & 385.91 & Shale & 11.24 & 30.90 \\
Argillaceous siltstone & 3.30 & 378.83 & Dolomicrite & 2.53 & 265.59 \\
Tuff & 3.26 & 296.13 & Calcareous mudstone & 4.25 & 96.57 \\
Silty dolomite & 4.77 & 318.81 & Dolomitic mudstone & 4.83 & 160.09 \\
Calcareous siltstone & 2.29 & 244.69 & Silty mudstone & 5.84 & 128.26 \\
\hline
\end{tabular}

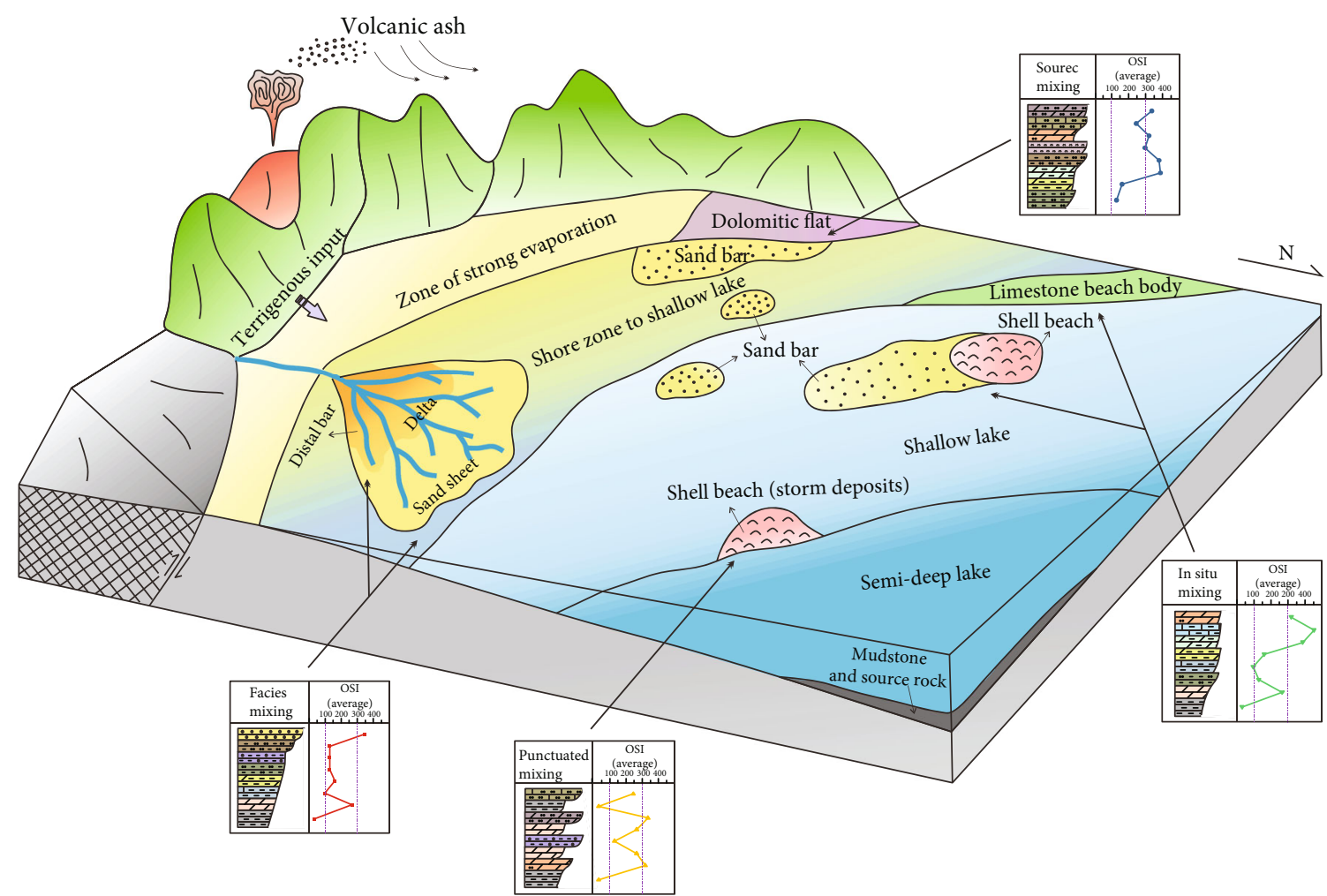

Figure 15: Generalized sedimentary model and mixing processes of the Lucaogou Formation, Jimusar Sag. Source mixing and in situ mixing areas are favorable for shale oil accumulation.

\section{Conclusions}

Based on a case study in the Middle Permian Lucaogou Formation of the Junggar Basin, China, we evaluate the controls on shale oil potential and accumulation of the complex, multi-source, and fine-grained mixed sedimentary strata in saline lacustrine basins.

The depositional environment controls the shale oil potential, as being reflected by different lithologies. The carbonate rocks and siltstones have the best shale oil potential. The excellent hydrocarbon generation potential of the adjacent mudstones provides a shale oil source. High-quality reservoir space in the carbonate rocks and siltstones provides storage of such oils through near-source migration and thus acts as the main control on shale oil accumulation.
Multiple provenance types and high-frequency stratigraphic changes control the complex lithofacies and mineralogy of the saline lacustrine sequences, which are conducive to fracturing during shale oil exploitation. Source mixing and in situ mixing of rocks are favorable for shale oil accumulation.

\section{Data Availability}

The data used to support the findings of this study are available from the corresponding author upon request.

\section{Conflicts of Interest}

The authors declare that they have no conflicts of interest. 


\section{Acknowledgments}

We thank colleagues from PetroChina Xinjiang Oilfield Company for their assistance during the sample collection and analysis. This work was jointly funded by the National Natural Science Foundation of China (Grant No. 41830425) and PetroChina Science and Technology Major Project (Grant Nos. 2017E-0401 and 2019E-2602).

\section{References}

[1] B. J. Cardott, "Thermal maturity of Woodford Shale gas and oil plays, Oklahoma, USA," International Journal of Coal Geology, vol. 103, pp. 109-119, 2012.

[2] Energy Information Administration, Annual Energy Outlook, 2012.

[3] D. M. Jarvie, R. J. Hill, T. E. Ruble, and R. M. Pollastro, "Unconventional shale-gas systems: the Mississippian Barnett Shale of north-central Texas as one model for thermogenic shale-gas assessment," AAPG Bulletin, vol. 91, no. 4, pp. 475-499, 2007.

[4] A. K. Uffmann, R. Littke, and D. Rippen, "Mineralogy and geochemistry of Mississippian and Lower Pennsylvanian black shales at the northern margin of the Variscan mountain belt (Germany and Belgium)," International Journal of Coal Geology, vol. 103, pp. 92-108, 2012.

[5] X. Tang, J. Zhang, X. Wang et al., "Shale characteristics in the southeastern Ordos Basin, China: implications for hydrocarbon accumulation conditions and the potential of continental shales," International Journal of Coal Geology, vol. 128-129, pp. 32-46, 2014.

[6] C. N. Zou, Unconventional Petroleum Geology, Geological Publishing House, 2014.

[7] C. N. Zou, Z. Yang, and R. Zhu, "Progresses in China's unconventional oil \& gas exploration and theoretical technologies," Acta Geologica Sinica - English, vol. 89, no. 3, pp. 938-971, 2015.

[8] C. N. Zou, R. Zhu, Z. Q. Chen et al., "Organic-matter-rich shales of China," Earth-Science Reviews, vol. 189, pp. 51-78, 2019.

[9] Y. Cho, E. Eker, I. Uzun, X. L. Yin, and H. Kazemi, "Rock characterization in unconventional reservoirs: a comparative study of Bakken, Eagle Ford, and Niobrara Formations," in SPE Low Perm Symposium, Denver, Colorado, USA, May 2016.

[10] E. Grubert, "The Eagle Ford and Bakken shale regions of the United States: a comparative case study," The Extractive Industries and Society, vol. 5, no. 4, pp. 570-580, 2018.

[11] B. Horsfield and H. M. Schulz, "Shale gas exploration and exploitation," Marine and Petroleum Geology, vol. 31, no. 1, pp. 1-2, 2012.

[12] S. H. Nordeng, "The Bakken petroleum system: an example of a continuous petroleum accumulation," North Dakota Department of Mineral Resources Newsletter, vol. 36, no. 1, pp. 21-24, 2009.

[13] T. Hu, X. Pang, Q. Wang et al., "Geochemical and geological characteristics of Permian Lucaogou Formation shale of the well Ji174, Jimusar Sag, Junggar Basin, China: implications for shale oil exploration," Geological Journal, vol. 53, no. 5, pp. 2371-2385, 2017.

[14] M. Wang, N. Sherwood, Z. Li et al., "Shale oil occurring between salt intervals in the Dongpu depression, Bohai Bay
Basin, China," International Journal of Coal Geology, vol. 152, pp. 100-112, 2015.

[15] M. Wang, R. W. T. Wilkins, G. Song et al., "Geochemical and geological characteristics of the Es $3^{\mathrm{L}}$ lacustrine shale in the Bonan sag, Bohai Bay Basin, China," International Journal of Coal Geology, vol. 138, pp. 16-29, 2015.

[16] W. Zhao, S. Hu, L. Hou et al., "Types and resource potential of continental shale oil in China and its boundary with tight oil," Petroleum Exploration and Development, vol. 47, no. 1, pp. 111, 2020.

[17] W. H. Li, S. Lu, H. Xue, P. Zhang, and Y. Hu, "Oil content in argillaceous dolomite from the Jianghan Basin, China: application of new grading evaluation criteria to study shale oil potential," Fuel, vol. 143, pp. 424-429, 2015.

[18] S. Lu, W. Huang, F. Chen et al., "Classification and evaluation criteria of shale oil and gas resources: discussion and application," Petroleum Exploration and Development, vol. 39, no. 2, pp. 268-276, 2012.

[19] M. E. Curtis, B. J. Cardott, C. H. Sondergeld, and C. S. Rai, "Development of organic porosity in the Woodford shale with increasing thermal maturity," International Journal of Coal Geology, vol. 103, pp. 26-31, 2012.

[20] R. M. Slatt and N. R. O'Brien, "Pore types in the Barnett and Woodford gas shales: contribution to understanding gas storage and migration pathways in fine-grained rocks," AAPG Bulletin, vol. 95, no. 12, pp. 2017-2030, 2011.

[21] P. C. Hackley, "Geological and geochemical characterization of the Lower Cretaceous Pearsall Formation, Maverick Basin, south Texas: a future shale gas resource?," AAPG Bulletin, vol. 96, no. 8, pp. 1449-1482, 2012.

[22] U. Hammes, H. S. Hamlin, and T. E. Ewing, "Geologic analysis of the Upper Jurassic Haynesville Shale in east Texas and west Louisiana," AAPG Bulletin, vol. 95, no. 10, pp. 1643-1666, 2011.

[23] R. J. Hill, D. M. Jarvie, J. Zumberge, M. Henry, and R. M. Pollastro, "Oil and gas geochemistry and petroleum systems of the Fort Worth Basin," AAPG Bulletin, vol. 91, no. 4, pp. 445-473, 2007.

[24] D. M. Jarvie, "Shale resource systems for oil and gas: part 2shale-oil resource systems," in Shale Reservoirs-Giant Resources for the 21st Century, vol. 97, pp. 89-119, 2012.

[25] C. Liang, Y. Cao, Z. Jiang, J. Wu, S. Guoqi, and Y. Wang, "Shale oil potential of lacustrine black shale in the Eocene Dongying depression: implications for geochemistry and reservoir characteristics," AAPG Bulletin, vol. 101, no. 11, pp. 1835-1858, 2017.

[26] R. G. Loucks, R. M. Reed, S. C. Ruppel, and U. Hammes, "Spectrum of pore types and networks in mudrocks and a descriptive classification for matrix-related mudrock pores," AAPG Bulletin, vol. 96, no. 6, pp. 1071-1098, 2012.

[27] K. Mba and M. Prasad, "Mineralogy and its contribution to anisotropy and kerogen stiffness variations with maturity in the Bakken Shales," in SEG Denver 2010 annual meeting, pp. 2612-2616, Denver, Colorado, 2010.

[28] S. L. Montgomery, D. M. Jarvie, K. A. Bowker, and R. M. Pollastro, "Mississippian Barnett Shale, Fort Worth basin, north-central Texas: gas-shale play with multi-trillion cubic foot potential," AAPG Bulletin, vol. 89, no. 2, pp. 155-175, 2005.

[29] C. Zou, Z. Yang, J. Cui et al., "Formation mechanism, geological characteristics and development strategy of nonmarine 
shale oil in China," Petroleum Exploration and Development, vol. 40, no. 1, pp. 15-27, 2013.

[30] L. Kuang, Y. Tang, D. Lei et al., "Formation conditions and exploration potential of tight oil in the Permian saline lacustrine dolomitic rock, Junggar Basin, NW China," Petroleum Exploration and Development, vol. 39, no. 6, pp. 700-711, 2012.

[31] Y. C. Wang, J. Cao, K. Tao, E. Li, C. Ma, and C. Shi, "Reevaluating the source and accumulation of tight oil in the Middle Permian Lucaogou Formation of the Junggar Basin, China," Marine and Petroleum Geology, vol. 117, p. 104384, 2020.

[32] A. R. Carroll and S. C. Brass, "Upper Permian lacustrine oil shales, southern Junggar Basin, Northwest China (1)," AAPG Bulletin, vol. 76, no. 12, pp. 1874-1902, 1992.

[33] A. R. Carroll and K. M. Bohacs, "Lake-type controls on petroleum source rock potential in nonmarine basins," AAPG Bulletin, vol. 85, no. 6, pp. 1033-1053, 2001.

[34] L. C. Kuang, G. Gao, B. L. Xiang, X. L. Wang, and C. Y. Wang, "Lowest limit of organic carbon content in effective source rocks from $\mathrm{P}_{2} \mathrm{l}$ in Jimusar Sag," Pet. Geol. Experiment, vol. 36, no. 2, pp. 224-229, 2014.

[35] H. M. Liu, S. Zhang, Y. S. Bao, Z. W. Fang, S. P. Yao, and Y. Wang, "Geological characteristics and effectiveness of the shale oil reservoir in Dongying sag," Oil and Gas Geology, vol. 40, no. 3, pp. 512-523, 2019.

[36] D. M. Zhi, Y. Tang, Z. F. Yang et al., "Geological characteristics and accumulation mechanism of continental shale oil in Jimusaer Sag, Junggar Basin," Oil and Gas Geology, vol. 40, no. 3, pp. 524-534, 2019.

[37] G. Gao, W. Zhang, B. Xiang, G. Liu, and J. Ren, "Geochemistry characteristics and hydrocarbon-generating potential of lacustrine source rock in Lucaogou Formation of the Jimusaer Sag, Junggar Basin," Journal of Petroleum Science and Engineering, vol. 145, pp. 168-182, 2016.

[38] M. R. Lin, K. Xi, Y. Cao, Q. Liu, Z. Zhang, and K. Li, "Petrographic features and diagenetic alteration in the shale strata of the Permian Lucaogou Formation, Jimusar Sag, Junggar Basin," Journal of Petroleum Science and Engineering, vol. 203, p. 108684, 2021.

[39] H. Pang, X. Q. Pang, L. Dong, and X. Zhao, "Factors impacting on oil retention in lacustrine shale: Permian Lucaogou Formation in Jimusaer Depression, Junggar Basin," Journal of Petroleum Science and Engineering, vol. 163, pp. 79-90, 2018.

[40] M. B. Allen, A. M. C. Engör, and B. A. Natal'in, "Junggar, Turfan and Alakol basins as Late Permian to Early Triassic extensional structures in a sinistral shear zone in the Altaid orogenic collage, Central Asia," Journal of the Geological Society, vol. 152, no. 2, pp. 327-338, 1995.

[41] S. Fang, C. Jia, Z. Guo, Y. Song, H. Xu, and L. Liu, "New view on the Permian evolution of the Junggar Basin and its implications for tectonic evolution," Earth Science Frontiers, vol. 13, no. 3, pp. 108-121, 2006.

[42] S. Fang, Y. Song, H. Xu, R. Fan, L. Liu, and X. Xu, "Relationship between tectonic evolution and petroleum system formation-taking the Jimusar Sag of Eastern Junggar Basin as an example," Petroleum Geology \& Exploration, vol. 29, no. 2, pp. 149-154, 2007.

[43] W. J. Xiao, C. Han, C. Yuan et al., "Middle Cambrian to Permian subduction-related accretionary orogenesis of northern Xinjiang, NW China: implications for the tectonic evolution of central Asia," Journal of Asian Earth Sciences, vol. 32, no. 2-4, pp. 102-117, 2008.

[44] Y. Jiang, Y. Liu, Z. Yang et al., "Characteristics and origin of tuff-type tight oil in Jimusaer sag, Junggar Basin, NW China," Petroleum Exploration and Development, vol. 42, no. 6, pp. 810-818, 2015.

[45] S. M. Zhang, Y. Cao, K. Liu et al., "Characterization of lacustrine mixed fine-grained sedimentary rocks using coupled chemostratigraphic-petrographic analysis: a case study from a tight oil reservoir in the Jimusar Sag, Junggar Basin," Marine and Petroleum Geology, vol. 99, pp. 453-472, 2019.

[46] Y. X. Wang, "The first national shale oil demonstration area has produced nearly 25000 tons of oil this year," Petroleum Refinery Engineering, vol. 50, no. 3, p. 41, 2020.

[47] G. H. Taylor, M. Teichmüller, A. Davis, C. F. K. Diessel, R. Littke, and P. Robert, Organic Petrology, Borntraeger, Berlin-Stuttgart, 1998.

[48] H. Amijaya and R. Littke, "Properties of thermally metamorphosed coal from Tanjung Enim Area, South Sumatra Basin, Indonesia with special reference to the coalification path of macerals," International Journal of Coal Geology, vol. 66, no. 4, pp. 271-295, 2006.

[49] K. Peters and M. R. Cassa, "Applied source rock geochemistry," in The Petroleum System-From Source to Trap, L. B. Magoon and W. G. Dow, Eds., vol. 60, pp. 93-120, AAPG Memoir, 1994.

[50] H. Sanei, H. I. Petersen, N. H. Schovsbo, C. Jiang, and M. E. Goodsite, "Petrographic and geochemical composition of kerogen in the Furongian (U. Cambrian) Alum Shale, central Sweden: reflections on the petroleum generation potential," International Journal of Coal Geology, vol. 132, pp. 158-169, 2014.

[51] B. P. Tissot and D. H. Welte, Petroleum Formation and Occurrence, Springer-Verlag, Berlin, second edition, 1984.

[52] B. Tissot, G. Deroo, and A. Hood, "Geochemical study of the Uinta Basin: formation of petroleum from the green river formation," Geochim Cosmochim Acta, vol. 42, no. 10, pp. 14691485, 1978.

[53] M. H. Hakimi, W. H. Abdullah, and M. R. Shalaby, "Geochemical and petrographic characterization of organic matter in the Upper Jurassic Madbi shale succession (Masila Basin, Yemen): origin, type and preservation," Organic Geochemistry, vol. 49, pp. 18-29, 2012.

[54] D. M. Jarvie, "Unconventional shale resource plays: shale gas and shale oil opportunities," Fort Worth Business Press meeting, 2008 .

[55] D. Y. Shao, T. Zhang, L. T. Ko et al., "Experimental investigation of oil generation, retention, and expulsion within type II kerogen-dominated marine shales: insights from gold-tube nonhydrous pyrolysis of Barnett and Woodford Shales using miniature core plugs," International Journal of Coal Geology, vol. 217, p. 103337, 2020.

[56] Y. H. Pan, M. Li, Y. Sun et al., "Characterization of free and bound bitumen fractions in a thermal maturation shale sequence. Part 1: acidic and neutral compounds by negativeion ESI FT- ICR MS," Organic Geochemistry, vol. 134, pp. 115, 2019.

[57] Z. H. Chen, W. Jiang, L. Zhang, and M. Zha, "Organic matter, mineral composition, pore size, and gas sorption capacity of lacustrine mudstones: implications for the shale oil and gas exploration in the Dongying depression, eastern China," AAPG Bulletin, vol. 102, no. 8, pp. 1565-1600, 2018. 
[58] S. Y. Yang and B. Horsfield, "Critical review of the uncertainty of Tmax in revealing the thermal maturity of organic matter in sedimentary rocks," International Journal of Coal Geology, vol. 225, p. 103500, 2020.

[59] R. G. Loucks and S. C. Ruppel, "Mississippian Barnett shale: Lithofacies and depositional setting of a deep-water shale-gas succession in the fort worth basin. Texas," AAPG Bulletin, vol. 91, pp. 579-601, 2007.

[60] C. N. Zou, Z. Yang, S. Z. Tao et al., "Continuous hydrocarbon accumulation over a large area as a distinguishing characteristic of unconventional petroleum: the Ordos Basin, NorthCentral China," Earth-Science Reviews, vol. 126, pp. 358-369, 2013.

[61] L. Xu, Q. S. Chang, C. K. Yang et al., "Characteristics and oilbearing capability of shale oil reservoir in the Permian Lucaogou Formation, Jimusaer sag," Oil and Gas Geology, vol. 40, no. 3, pp. 535-549, 2019.

[62] E. Azomani, K. Azmy, N. Blamey, U. Brand, and I. al-Aasm, "Origin of Lower Ordovician dolomites in eastern Laurentia: controls on porosity and implications from geochemistry," Marine and Petroleum Geology, vol. 40, pp. 99-114, 2013.

[63] B. Jamtveit and B. W. D. Yardley, "Fluid flow and transport in tocks: an overview," Springer, 1997.

[64] Y. G. Hou, F. Wang, S. He, T. Dong, and S. Wu, "Properties and shale oil potential of saline lacustrine shales in the Qianjiang Depression, Jianghan Basin, China," Marine and Petroleum Geology, vol. 86, pp. 1173-1190, 2017.

[65] Z. M. Li, G. L. Tao, M. W. Li et al., "Discussion on prospecting potential of shale oil in the $3 \mathrm{rd}$ sub-member of the Triassic Chang 7 member in Binchang block, southwestern Ordos Basin," Oil and Gas Geology, vol. 40, no. 3, pp. 558-570, 2019.

[66] F. X. Ning, "The main control factors of shale oil enrichment in Jiyang depression," Acta Petrolei Sinica, vol. 36, no. 8, pp. 905-914, 2015.

[67] J. Zhang, X. Xu, J. Bai et al., "Enrichment and exploration of deep lacustrine shale oil in the first member of Cretaceous Qingshankou Formation, southern Songliao Basin, NE China," Petroleum Exploration and Development, vol. 47, no. 4, pp. 683-698, 2020.

[68] Z. Qiu, Z. Shi, D. Dong et al., "Geological characteristics of source rock and reservoir of tight oil and its accumulation mechanism: a case study of Permian Lucaogou Formation in Jimusar Sag, Junggar Basin," Petroleum Exploration and Development, vol. 43, no. 6, pp. 1013-1024, 2016.

[69] J. F. Mount, "Mixing of siliciclastic and carbonate sediments in shallow shelf environments," Journal of Geology, vol. 12, no. 7, pp. 432-435, 1984.

[70] Y. Ding, Z. W. Li, F. Feng et al., "Mixing of lacustrine siliciclastic-carbonate sediments and its significance for tight oil exploration in the Daanzhai Member, Ziliujing Formation, Lower Jurassic, in Longgang area, central Sichuan Basin," Journal of Geological Review, vol. 59, no. 2, pp. 389-400, 2013.

[71] G. Y. Dong, H. D. Chen, J. W. Li et al., "The Cambrian mixed sedimentation around Bohai Sea Bay basin," Journal of Acta Geologica Sinica, vol. 83, no. 6, pp. 800-811, 2009.

[72] K. Ma, J. G. Hou, Y. M. Liu, Y. Q. Shi, L. Yan, and F. L. Chen, "The sedimentary model of saline lacustrine mixed sedimentation in Permian Lucaogou Formation, Jimsar sag," Acta Petrolei Sinica, vol. 38, no. 6, pp. 636-648, 2017.
[73] G. Z. Wang, "Mixed sedimentation of recent reefoid carbonates and terrigenous clastics in the north continental shelf of the South China Sea," Journal of Palaegeography, vol. 3, no. 2, pp. 47-54, 2001.

[74] J. Y. Zhang, G. Liu, Z. Cao et al., "Characteristics and formation mechanism of multi-source mixed sedimentary rocks in a saline lake, a case study of the Permian Lucaogou Formation in the Jimusaer Sag, northwest China," Marine and Petroleum Geology, vol. 102, pp. 704-724, 2019.

[75] H. Wu, W. Hu, J. Cao, X. Wang, X. Wang, and Z. Liao, “A unique lacustrine mixed dolomitic-clastic sequence for tight oil reservoir within the Middle Permian Lucaogou Formation of the Junggar Basin, NW China: reservoir characteristics and origin," Marine and Petroleum Geology, vol. 76, pp. 115$132,2016$. 